\title{
KONSEP INTERSUBJEKTIVITAS \\ DALAM PHENOMENOLOGY OF SPIRIT \\ KARYA GWF HEGEL
}

\author{
Oleh: \\ Bito Wikantoso \\ Fakultas Filsafat \\ Universitas Gadjah Mada (UGM), Yogyakarta \\ bito_wikan@gmail.com
}

\begin{abstract}
One of the basic concepts of the Hegel's critic on the modern society which differentiate it from that of the liberalism is the concept of subjectivity. For Hegel, the self-consciousness is constructed of the self-consciousness of others. This study concerns the intersubjectivity comprensively explained within the Hegel's system of philosophy. Thus, it has made the Hegel's idea is more outstanding than what the other philosophers of the same period have.
\end{abstract}

\begin{abstract}
Abstrak
Salah satu konsep dasar kritik Hegel atas masyarakat modern yang membedakannya dari liberalisme adalah konsep tentang subjektivitas. Bagi Hegel, kesadaran-diri terbentuk dari interaksi kompleks dengan kesadaran-diri lainnya. Studi ini, melihat konsep intersubjektivitas yang diuraikan Hegel dalam sistem filsafatnya. Sehingga dapat dilihat kelebihan Hegel dibandingkan pandangan pemikir sejamannya.
\end{abstract}

Kata kunci: Hegel, Intersubjektivitas, Phenomenology of Spirit

\section{PENDAHULUAN}

\subsection{Latar Belakang Masalah}

Semua bangsa terlibat proses modernisasi. Manifestasi proses ini pertama kali nampak di Inggris abad delapan belas yang disebut revolusi industri. Sejak itu gejala tersebut meluas ke segala penjuru dunia. Penyebaran ini dianggap sebagai sesuatu yang biasa, sehingga tidak tersedia tempat kemungkinan adanya negara yang karena sesuatu hal tidak terlibat dalam proses modernisasi itu (Schoorl, 1980:1).

Manusia modern memiliki kepercayaan berbeda-beda tentang diri mereka dan abad modern ini. Ada yang merasa terbebaskan dari tradisi dan memuji perubahan ini. Ada pula yang meyakini manusia modern terputus dari nilainilai dan pandangan hidup tradisional. Mereka yang mencemaskan hasil perubahan itu, mengatakan bahwa masyarakat modern kehilangan akar-akar kehidupan sosialnya. Mereka menunjukkan pada masyarakat konsumen yang aktif sebagai bukti dampak masyarakat modern. Hal itu terlihat dari sikap gaya hidup konsumen yang serba berubah sampai dengan lingkup pembicaraan yang dibentuk industri komunikasi massa.

Manusia modern dapat membayangkan hidup di dalam wilayah kehidupan yang tidak dipersoalkan seperti yang dilakukan masyarakat di daerah lain atau pada masyarakat jaman dahulu. Tetapi kenyataannya, mereka tidak mengi- 
kuti tradisi secara alami dan tidak mendefinisikan diri berdasarkan norma-norma sosial yang tetap. Mereka menyangkal tempat hidupnya berubah. Tetapi ketika hidup bersama di dalam suatu aturan sosial, aturan itu merupakan hal yang asing. sikap hidup mereka jauh berbeda dengan yang terjadi pada prajurit Mataram atau petani tradisional pada awal abad sembilan belas. Manusia modern lebih mungkin memiliki pilihan-pilihan di luar aturan sosial itu. Tetapi apakah kehendak dan nilai-nilai yang mengkerangkai tindakan dan cara pikir manusia itu sungguh pasti ? Apakah manusia membuat pilihan dan memutuskan tindakan secara otonom dan bebas.

Dalam wawasan historis dapat dikatakan bahwa sejak Renaissance abad enam belas dan memuncak pada Aufklarung abad delapan belas, dalam masyarakat Barat muncul apa yang disebut Max Weber: disenchantment of the world ("hilangnya pesona dunia"). Lingkungan lahiriah tidak lagi mengepung dengan kekuatan-kekuatan gaibnya yang menakutkan sekaligus mempesona. Lingkuhgan ini sekarang dihadapi sebagai suatu dunia material atau objek belaka (Hardiman, 1993: 120). Konsekuensi logis dari peristiwa ini adalah otonomi dan kebebasan menafsirkan realitas. Kebebasan tafsir itu memunculkan pluralitas gagasan, persaingan bebas produk intelektual (Mannheim, 1991: 15).

Filsafat modern dimulai dengan pembalikan pusat kenyataan yaitu penemuan subjektivitas, seperti yang dikatakan Descartes dalam Discourse on Method: "manusia adalah tuan dan penguasa dunia" (Kolb, 1986: 2). Sekarang bukan batin manusia yang harus menyesuaikan diri dengan lingkungan lahiriah, melainkan alam yang harus menyesualkan diri dengan normanorma batin manusia. Kosmosentrisme berubah menjadi antroposentrisme.

Berpangkal dari subjektivitas ini, seperti yang dikatakan Hardiman (1993: 121-124), muncul beberapa aspek kesadaran modern lain, yakni: progres, individuasi, emansipasi dan sekularisasi. Progres atau kemajuan adalah suatu kesadaran bahwa waktu merupakan sebuah arus yang tak bisa diulang. Sedangkan subjektivitas berarti individu membebaskan diri dari entitas-entitas kolektif. Proses ini kemudian disebut "individuasi" yaitu individu menyadari bahwa dirinya berbeda dari masyarakatnya. Dia itu otonom, dalam arti menghasilkan nomos (hukum)-nya sendiri. Yang dimaksud dengan emansipasi adalah individu mendorong praktik mengubah eksistensi yang terkait dengan struktur sosial. Akhirnya yang disebut sekularisasi adalah sebentuk kesadaran memisahkan antara sakral dan profan.

Dalam terang triad dari Peter L. Berger yaitu: eksternalisasi - objektivasi - internalisasi, kesadaran modern merupakan rangkaian perubahan dan perkembangan kesadaran manusia. Kesadaran modern dengan segala aspek, mengeksternalisasikan diri membentuk dunia modern, berupa realitas kesadaran objektif. Kesadaran modern objektif ini selanjutnya diinternalisasi kembali oleh kesadaran subjektif manusia.

Eksternalisasi kesadaran modern yang terwujud dalam dunia modern, menurut Berger (1992: 29 \& 44), ciri sentralnya adalah produksi berteknologi dan birokrasi. Selain itu Berger (1990: 21) dan Poole (1993: xx-xxi) mengatakan bahwa masyarakat pasar dan kapitalisme juga merupakan ciri modernitas.

Kapitalisme, didefinisikan oleh Max Weber sebagai usaha kegiatan ekonomi yang ditujukan pada suatu pasar dan dipacu menghasilkan laba melalui pertukaran di pasar (Berger, 1990: 2123). Kegiatan pokok kapitalisme berlangsung di antara dua kutub konsumsi dan produksi. Konsumsi adalah pemuasan keinginan tertentu manusia. Jika pemuasan keinginan dianggap sebagai kebahagiaan, lalu kapitalisme tampaknya menjanjikan bertambah banyaknya kebahagiaan. Sebaliknya, produksi merupakan tindakan atau proses transformasi. Dalam bentuk intinya, produksi meliputi perubahan objek-objek dan bahan-bahan yang disediakan oleh alam, menjadi bentuk-bentuk saat objek-objek dan bahanbahan tersebut cocok dipakai oleh manusia.

Kapitalisme mengembangkan kekuatan manusia dalam mengubah alam. Ini meliputi mesin-mesin baru, bentuk kerja dan macam-macam pengetahuan baru: mengadakan keahlian dan perencanaan dan koordinasi baru. Kekuasaan atas alam telah berkembang berduaan secara simbiosis dengan kekuasaan manusia atas manusia lain. Macam-macam kekuasaan di sini tidak hanya kemampuan mengubah alam, tetapi kekuasaan itu lebih-lebih merupakan kemampuan memperluas dan menciptakan. Kekuasaan tidak membatasi apa yang sudah ada, melainkan mengadakan hal yang baru. Kekuasaan inilah yang memainkan peranan penting di dalam du- 
nia kapitalis dan merupakan salah satu nilai dominannya.

Masyarakat pasar terutama dicirikan ketiga unsur ini: pertama, adanya pembagian kerja dalam masyarakat: kedua, adanya kerangka kerja hukum mengenai milik pribadi dan kontrak, terakhir, adanya kecenderungan individual bertindak demi kepentingan sendiri (Poole, 1993: 3-4). Dalam masyarakat pasar, masing-masing individu akan berusaha memaksimalkan pemenuhan keinginan-keinginannya. Karena segalanya sama, ia hanya dapat melakukan ini dengan mengambil bagian dalam hubungan-hubungan pasar, dan hal itu menuntutnya mengerahkan tenaga menghasilkan barang-barang yang diinginkan orang lain. Dengan demikian individu yang berkepentingan diri harus produktif secara sosial. Cara terbaik bagi seseorang memperbaiki kedudukan adalah menjadi lebih efisien daripada saingan-saingannya. Jadi pasar mengutamakan efisiensi produksi. Dalam masyarakat pasar apa yang merupakan keinginan-keinginan akan menjadi kebutuhan-kebutuhan. Apabila keinginan dan kebutuhan meningkat, pasar akan meningkatkan menyediakan sarana-sarana yang memuaskan keinginan mereka.

Proses produksi tidak sekedar alat-alat industri. Selain itu dalam diri pekerja ada pengetahuan tentang pekerjaan khusus, yang mengharuskan dia bekerja dengan cara-cara tertentu. Pengetahuan pekerja tentang bidang kerja bukan sekedar isi yaitu cara-cara dan aturanaturan yang dilatihkan secara khusus, sehingga ia terampil di bidangnya. Berger (1992: 31-32) mengatakan bahwa pengetahuan pekerja juga mengenai gaya yang ciri-cirinya dapat dilukiskan sebagai berikut. Ciri yang paling penting adalah sifat mekanistis, kemudian sifat yang berkaitan erat adalah sifat dapat direproduksi dan akhirnya sifat dapat diukur.

Selain itu, suatu unsur strategis dalam gaya kognitif yang dibicarakan adalah komponensialitas (sifat terdiri dari komponen-komponen). Realitas ditata menurut pengertian komponenkomponen yang dipahami dan dimanipulasi sebagai satuan-satuan atomistik. Jadi segala sesuatu dapat dianalisa, dipisah-pisahkan dan dipersatukan kembali berdasarkan komponen itu. Maka dari itu muncullah sifat ketergantungan antar komponen itu dengan tata urutnya. Dalam kondisi sama, hasil-hasil yang sama dapat diperoleh. Komponen-komponen terus menerus sal- ing tergantung secara rasional, terkendalikan dan teramalkan. Setiap komponen tidak memiliki satu fungsi tunggal, setiap komponen dapat saling disusun dengan cara yang berbeda-beda. Berkaitan erat dengan hal itu adalah sifat abstraksi implisit, sifat yang meresapi. Setiap tindakan, bagaimanapun konkretnya, dapat dipahami menurut kerangka acuan yang abstrak.

Berger (1992: 47-54) juga menjelaskan yang dimaksud dengan birokrasi. Secara umum, birokrasi dimengerti sebagai tata langkah yang layak. Birokrasi dianggap berjalan menurut aturan-aturan dan tata urut rasional. Dalam ruang lingkup politik hal itu berhubungan dengan ide kelegalan dan tata langkah menurut hukum. Eksistensi birokrasi itu sendiri dilegitimasikan oleh kelegalan itu, dan dianggap bahwa birokrasi akan bekerja sesuai dengan hukum.

Pengertian pokok tentang sistem birokrasi ialah pengertian kompetensi tiap yuridikasi dan tiap badan di dalamnya kompeten hanya atas ruang lingkup kehidupan yang menjadi tugasnya dan harus memiliki pengetahuan mahir yang sesuai dengan ruang lingkup itu.

Ciri gaya kognitif birokrasi yang menonjol adalah keteraturan. Tiap birokrasi menghasilkan sistem kategori yang dapat memberikan tempat kepada segala sesuatu dalam yuridikasi tertentu dan menjadi kerangka acuan menangani segala sesuatu. Birokrasi mengandaikan sifatdapat ditata yang umum dan otonom. Pada prinsipnya, segala sesuatu dapat ditata menurut istilah-istilah birokrasi. Karena sifat formalnya yang abstrak, birokrasi pada prinsipnya dapat diterapkan pada fenomena manusiawi manapun juga.

Ada asumsi umum tentang sifat dapat diramalkan. Tata langkah tertentu diketahui dan demikian dapat diramalkan. Ada pengharapan umum tentang keadilan. Diharapkan bahwa tiap orang dalam kategori yang relevan akan diperlakukan secara sama. Orang pada umumnya mengharapkan agar birokrasi bekerja secara impersonal dan "kenetralan afektif". Akhirnya, terdapat pengertian keanoniman. Kompetensi, tata langkah, hak-hak, dan kewajiban-kewajiban birokrasi tidaklah melekat pada individu-individu konkret tetapi pada para pejabat dan klien kantor-kantor birokrasi. Di dalam kerangka acuan birokrasi, korupsi adalah setiap pelanggaran terhadap asas keanoniman yang dominan itu.

Apa yang muncul dari kombinasi unsur-unsur gaya kognitif yang disebutkan di atas dapat 
dilukiskan sebagai keanoniman itu tidak hanya diakui sebagai keperluan pragmatis tetapi diberi kepatuhan sebagai perintah moral. Dalam birokrasi, keanoniman ditentukan secara intrinsik dan disahkan secara moral sebagai suatu prinsip hubungan sosial. Jadi, anggapan persamaan hak semua orang dalam suatu kategori birokrasi yang relevan bukanlah suatu tuntutan teknis melainkan suatu aksioma etika birokrasi. Sistem birokrasi sebagai keseluruhan dipandang mempunyai kewajiban-kewajiban moral terhadap para kliennya. Ini tentu saja merupakan dasar keabsahan birokrasi.

Kesadaran lebih berada pada lingkungan batiniah. Eksternalisasi adalah penglahiran kesadaran, yang kemudian membentuk objektivitas dalam realitas sosial. Lingkungan dunia lahiriah baru sebagai hasil ciptaan kesadaran modern adalah pranata-pranata modern.

Menurut Marx Weber, kekuatan pendorong terpenting momen objektif dunia modern adalah apa yang disebutnya "rasionalisasi" yaitu tindakan progresif dalam berpikir rasional dan teknik-teknik rasional atas setiap sektor masyarakat (Berger, 1990: 37). Dengan ini dimaksudkan bahwa prinsip-prinsip rasionalitas tertentu sudah mulai disaturagakan di dalam institusi-institusi dan praktik-praktik dunia modern - termasuk pasar dan organisasi produksi kapitalis, birokrasi dan aparat-aparat hukumnya, dan pelembagaan ilmu pengetahuan serta pendidikan. Mereka yang hidup dalam institusi-institusi dan praklik-praktik ini tak bisa berbuat apa-apa kecuali hidup di dalam saluran-saluran yang tersedia bagi mereka dalam masyarakat. Rasionalisasi, dalam arti institusional atau objektif, menghasilkan bentuk-bentuk rasionalitas yang mampu mengatur pemikiran dan tingkah laku manusia modern.

Jadi, secara sederhana dapat dikatakan bahwa rasionalitas dominan dalam dunia modern adalah rasionalitas instrumental (rasionalitas bersifat formal, strategis dan efektif). Bentuk rasionalitas semacam ini paling jelas ada di masyarakat pasar dalam proses produksi dan pemasaran. Individu-individu bersifat rasional dalam arti ini, mereka menyeleksi dari rentetan tindakan-tindakan yang memungkinkan mereka mencapai mencapai tujuan tertentu.

Momen internalisasi dalam triad Berger adalah tahap pembatinan kembali hasil-hasil objektivasi dengan mengubah struktur lingkun- gan lahiriah itu menjadi struktur lingkungan batiniah, yakni kesadaran subjektif. Tetapi pembatinan realitas objektif dalam masyarakat modern mengalami kegagalan. Dalam situasi realitas objektif kesadaran modern mengalami keterpecahan "diri"nya dan aneka peran yang terbuka terhadap konflik satu sama lain. Makna jati dirinya menjadi kabur.

Situasi keterpecahan diri manusia modern itu dilukiskan Berger (1992: 165-179) melalui istilah "ketakberumahan" (homeless). Dalam sruktur-struktur masyarakat modern yang pluralitis, makin banyak individu yang senantiasa berubah. Individu senantiasa silih berganti mengalami konteks-konteks sosial yang sangat berlainan dan kerap kali bertentangan. Berkenaan dengan riwayat hidupnya, individu berpindahpindah berganti-ganti dari dunia sosial yang satu ke dunia sosial yang lain yang saling berbeda sekali. Tidak hanya makin banyak jumlah individu dalam masyarakat modern tercabut dari lingkungan sosial mereka, yang asli, tetapi, selain itu, tidak ada lingkungan baru pengganti lingkungan lama yang berhasil menjadi "rumah" yang sebenarnya.

Dalam situasi ketakberumahan, manusia modern tidak mampu membatinkan lingkungan lahiriahnya secara aktif. Manusia modern mengalami kesulitan internalisasi. Akibatnya dia malah menjadi sistem-sistem objektif yang diciptakannya. Momen objektifnya, masih berdiri tegar di luar kontrol kesadaran.

Sejak awal perkembangan dunia modern, menurut Poole (1993: 23-29), para filsuf telah memberi tanggapan terhadap jaman itu. Immanuel Kant merupakan filsuf yang memberi landasan moral bagi masyarakat modern. Kant memberikan sebuah rute yang baik bagi jalan ke moralitas pasar. Pasar mengandaikan suatu kerangka kerja pemilikan dan kontrak. Prasyarat yang dituntut masyarakat komersial adalah individu-indiividu yang mampu menunaikan kewajiban mereka karena hal itu merupakan kewajiban mereka, yakni mengakui milik orang lain dan mengikat kontrak dengan maksud menepatinya. Kant mampu dengan cemerlang merumuskan suatu moralitas yang berpusat pada kebebasan dan kewajiban.

Bagi Kant, pengertian yang relevan tentang kebebasan yang terkait dengan konsep rasionalitas, memiliki universalitas formal. Artinya, sejauh manusia ini mahluk rasional, manusia men- 
gakui dirinya tunduk di bawah prinsip-prinsip yang dapat diterapkan. Prinsip-prinsip itu oleh Kant disebut maksim-maksim, dikenakan kepada semua mahluk rasional di dalam situasi yang sama. Daya dorong utama penalaran Kant ini, adalah bahwa individu yang paling mementingkan diri sekalipun harus mengakui bahwa klaimklaim yang ia buat bagi dirinya sendiri mesti juga bisa diterima orang-orang lain yang berada dalam kedudukan serupa. Model moralitas Kant ini, yaitu: kesetiaan pada prinsip-prinsipnya, secara tidak langsung memelihara struktur pasar.

Konsep-konsep yang mendefinisikan modernitas dalam kaitannya dengan kebebasan dan individualitas modern, menurut Kolb (1986:10), dikemukakan juga oleh Max Weber. Ia mempostulatkan individu adalah pencipta makna. Dunia sosial dengan makna dan aturan-aturannya adalah hasil konstruksi bersama-sama antar individu-individu. Gema Kantian nampak dalam pembahasan pada bagian ini. Tetapi Weber bertentangan dengan Kant. ia membuat makna menjadi tindakan pembebasan pilihan individu. Memberi persyaratan yang disebut metodologi individualisme. Metodologi itu mengikuti pandangan modern yang secara eksplisit mengakui kepercayaan dan kebiasaan individual sebagai basis konstruksi sosial tentang diri manusia lebih dekat kebenarannya dibandingkan keyakinan tradisional.

Pada intinya dalam masyarakat modern jelas terdapat individualisme atau otonomi individu menurut Weber itu. Individu, melalui otonominya, membebaskan diri dari ikatan komunal yang telah tertanam kuat di dalam dirinya. Orangorang seperti itu dapat berusaha dan pergi mencari kesempatan-kesempatan baru tanpa terhambat tradisi, adat istiadat dan pantanganpantangan kolektif. Kemudian dalam proses sosialisasi, mereka mempunyai tanggung jawab pribadi yang kuat. Hal ini mengharuskan adanya suatu disiplin yang kuat dan rasionalitas yang tinggi. Rasionalitas di sini diartikan sebagai $r a-$ sionalitas fungsional, sikap kepala dingin, tidak main-main, siap mengatasi persoalan kehidupan pada umumnya dan tentu saja kehidupan ekonomi pada khususnya.

Liberalisme dewasa ini, menurut Poole (1993: 99-98), juga menerima tesis Weber tentang konsep individualisme itu. Bagi kaum liberal, dunia tidak mengandung nilai-nilai objektif dan mereka menekankan kebebasan individu yaitu: individu bebas memilih nilai-nilainya sendiri. Kaum liberal membayangkan masyarakat majemuk, dicirikan berbagai macam individu memilih sendiri konsep-konsep tentang kehidupan yang baik. Di batas-batas tertentu, tak ada standar-standarobjektif menilai tindakantindakan penciptaan nilai itu dan karenanya tak ada alasan mengira satu cara hidup lebih unggul terhadap yang lain. Wilayah pembatasan hubungan antar individu hanyalah konsep keadilan.

Proyek liberalisme menyusun pandangan mengenai keadilan yang mempertahankan subjektivitas. Kant-lah yang memberikan inspirasi utama bagi para teoritikus liberal dewasa ini mempelajari konsep keadilan. Prinsip keadilan ditemukan, tidak dalam jaringan dunia lahiriah, atau juga tidak dalam isi keinginan atau pilihan individu melainkan di dalam struktur pikiran dan tindakan manusia. Dalam arti tertentu, ini adalah struktur subjektivitas. Tetapi kalau struktur itu universal, maka subjektivitas akan mempunyai status impersonal.

Kant mengatakan bahwa peran kunci yang menentukan isi dan kekuatan prinsip subjektivitas universal dimainkan konsep rasio. Manusia mematuhi tuntutan keadilan sejauh mereka mahluk-mahluk rasional. Tuntutan-tuntutan ini tidak akan menjadi kendala eksternal, melainkan akan diterima orang yang memenuhi tuntutan itu. Prinsip-prinsip hak dalam arti ini adalah pengendalian diri dan pembatasanpembatasan pengekangan diri. Oleh karena itu, semua tindakan diri adalah hasil kebebasan.

Pemutlakkan liberalisme terhadap subjektivitas sebagai satu-satunya ruang yang digunakan sebagai sumber nilai dan pengetahuan ini memisahkan ikatan-ikatan konstitutif antara individu dan masyarakat. Proses ini juga merupakan proses pengosongan manusia dari sumber-sumber nilai-nilai mereka sendiri. Hal ini memperlihatkan bahwa liberalisme gagal menghadapi kearbitreran kebebasan individu.

Kehancuran nilai-nilai objektif dan ketidakmampuan individu memiliki nilai-nilai sendiri merupakan dasar munculnya nihilisme. Nihilisme adalah kekosongan kebebasan absolut. Liberalisme, menurut Poole $(1993,188)$, adalah nihilisme yang cair. Paham ini secara implisit mengakui nihilisme pada pusat eksistensi sosial modern, dan mengusahakan membendung nihilisme di dalam batas-batas yang diperlukan agar kehidupan sosial tetap berlangsung. Tetapi 
liberalisme memiliki hakikat nihilisme, yaitu dorongan ke arah kekuasaan dan konsumsi yang merupakan kedok-kedok nihilisme dalam dunia modern. Kedok-kedok ini menghancur leburkan atau membongkar batas-batas, khususnya batas-batas moralitas. Jadi proyek modernitas itu gagal.

Dampak negatif situasi dunia modern bagi kesadaran manusia sudah dikritik para filsuf sejak puncak pembelaan filsafat terhadap modernitas pada awal perkembangannya. Menurut Poole (1993: 126), G.W.F. Hegel, merupakan filsuf yang sangat berbeda dari segala para filsuf di abad kedelapan belas dan sembilan belas. Para filsuf pada abad-abad tersebut pada umumnya sangat memuja dan begitu berharap kepada masyarakat baru yang sedang mulai berkembang itu. Sebaliknya Hegel mengakui masalah-masalah yang dihadapi masyarakat modern, tetapi pemecahan yang diberikan oleh liberalisme terhadap persoalan masyarakat modern, menurut Hegel, sangat keliru.

Salah satu konsep dasar kritik Hegel atas masyarakat modern yang membedakannya dari liberalisme adalah konsep tentang subjektivitas. Bagi Hegel, kesadaran-diri terbentuk dari interaksi kompleks dengan kesadaran-diri lainnya. Tulisan ini, melihat konsep intersubjektivitas yang diuraikan Hegel dalam sistem filafatnya. Sehingga dapat dilihat kelebihan Hegel dibandingkan pandangan pemikir sejamannya.

Tetapi Hegel termasuk seorang yang paling sukar dipahami di antara para filsuf yang pernah hidup. Ia menghasilkan karya dalam jumlah besar. Selain itu, filsafat Hegel sangat gelap dan menempatkan pembaca dihadapan sejumlah besar masalah-masalah interpretasi (Layendecker, 1983: 177). Ketidakjelasan filsafat Hegel ini, menyulitkan dalam meringkasnya (Inwood, 1983: 1). Oleh karena itu, penelitian ini membatasi masalah hanya pada konsep intersubjektivitas di dalam salah salu karya dari sistem filsafat Hegel yaitu Phenomenology of Spirit. Karya Hegel ini memiliki posisi penting bagi karya-karya Hegel yang lain.

Selain faktor kesulitan filsafat Hegel: luas pemikiran dan karyanya dalam jumlah besar, pembatasan penelitian ini disebabkan juga oleh beberapa kendala dalam diri peneliti. Kendala itu meliputi: Dasar yang tidak cukup kuat dalam pemikiran filosofis, baik sistematis maupun historis. Kemudian, daya sintetis-historis yang jauh dari cukup sehingga peneliti mengalami kesulitan dalam menyatukan semua konsep dalam filsafat Hegel.

\subsection{Landasan Teori}

Hegel melihat dunia sebagai sebuah keseluruhan model tentang Roh, yaitu: Roh memproyeksikan objek yang dapat disadari subjek. Objek-objek ini berkembang, melalui tahap-tahap, ke arah manusia. Manusia sebagai kesadaran tidak hanya menyadari alam, tetapi juga roh kosmis itu sendiri dalam hubungannya dengan alam. Perkembangan manusia dan pemikirannya, hadir dalam perluasan kesadaran diri Roh kosmis. Kesadaran ini dilengkapi oleh sistem Hegel sendiri, yang ia pandang sebagai puncak perkembangan Roh, saat keseluruhan proses menjadi sama sekali jernih bagi manusia (Inwood, 1983: 2).

Partisipasi roh manusia dalam Roh dunia itu memungkinkan perubahan kesadaran dari tahap yang paling rendah ke tahap yang paling tinggi. Dan ini yang dideskripsikan Hegel dalam Phenomenology of Spirit yaitu sejarah kesadaran. Hegel mulai dengan kesadaran alami (natural consciousness) dan mengubah melalui gerakan dialektis perkembangan kesadaran, memperlihatkan bagaimana level lebih rendah termasuk dalam level lebih tinggi sesui dengan sudut pandang lebih memadai, sampai akhirnya mencapai level pengetahuan absolut (Copleston, 1963: 181).

Metode Hegel disebut "dialektis", karena mengikuti dinamika dalam pikiran dan kenyataan itu. Dialektik itu diungkapkan sebagai tiga langkah: dua pengertian bertentangan, kemudian didamaikan.

(Thought) in its very nature is dialectical, and that, as understanding, it must fall into contradiction -the negative of itself...... When thought grows hopeless of ever achieving, by its own means, the solution of contradiction which it has by its own action brought upon itself, it turns back to those solutions of question with which the mind had learned to pacify itself in some of its modes and forms' (Hegel, 1915: 5).

(Pikiran pada hakekatnya adalah dialektik, dan sebagai pemahaman, hal itu harus masuk ke dalam kontradiksi-negasi dari dirinya sendiri... Ketika pikiran berkembang tanpa 
harapan sesungguhnya mencapai sukses, oleh cara-cara miliknya, kesimpulan dari kontradiksi yang mana ha1 itu melalui tindakan sendiri mengarahkan dirinya sendiri, mengembalikan solusi-solusi itu dari pertanyaan yang dengan pertanyaan itu roh belajar menenteramkan diri dalam beberapa cara dan bentuk lain).

Sebagai titik tolak metodis, Hegel mengambil salah satu pengertian atau konsep yang lazim dianggap jelas. Pengertian itu mulai diambil menurut arti sehari-hari, spontan dan bukan reflektif. Oleh karena Hegel, konsep atau pengertian itu dirumuskan dengan jelas, sehingga identik dengan dirinya sendiri dan menyangkal segala hal atau pengertian lain. Dengan memikirkan dalam keterbatasan itu, Hegel menerangkan secara radikal menurut segala ekstrimnya. Tetapi dalam proses pemikiran itu dengan tiba-tiba, konsep atau pengertian itu mulai kehilangan ketegasan dan kepadatannya mulai menjadi cair dan remuk.

Pada langkah kedua, pemikiran konsep atau pengertian yang pertama itu sendiri membawa orang ke konsep pengertian yang menimbulkan pengertian ekstrim yang lain. Konsep atau pengertian yang muncul dalam langkah kedua itu diperlakukan sama seperti langkah pertama. Pada langkah ketiga, kedua langkah satu-dua memuat negasinya sekarang kedua-duanya telah padat dan konkret. Mereka menjadi Aufgehoben, yang dapat berarti: melarutkan, menghapuskan, meniadakan, tetapi juga mengangkat, membawa ke taraf lebih tinggi, bahkan juga menyimpan (Bakker, 1984: 101-103).

Hegel mengartikan realitas sebagai proses pendobrakkan atau pernyataan diri akal budi. Manusia mengalami proses itu dalam kesadaran sebagai peningkatan pengertian menyeluruh dan kesadaran itu sekaligus mengungkapkan sebuah proses peningkatkan rasionalitas dalam sejarah. Dan karena rasionalitas menyatakan diri melalui negativitas, negativitas adalah prinsip kemajuan baik dalam realitas itu maupun dalam pengertian tentang realitas itu dan dua-duanya merupakan satu proses. Hegel menguraikan proses itu dl satu pihak sebagai proses perjalanan kesadaran-diri dari pengetahuan inderawi sampai pengetahuan absolut, di lain pihak sebagai perkembangan Roh, dari Roh subjektif melalui Roh objektif ke Roh absolut (Magnis-Suse- no, 1993: 19).

Dialektika adalah kesadaran bahwa setiap bentuk atau momen dalam isolasinya tidak benar, maka memanggil penyangkalan dan dalam arti ini juga memuatnya saat penyangkalan itu sendiri lalu perlu disangkal, dan seterusnya. Jadi dialektika, menurut Magnis-Suseno (1993: 19-21), dalam sintesis, memanggil sesungguhnya antitesis baru. Itulah prinsip negativitas.

Sistem dual ini dapat diketemukan dalam teks Phenomenoloqv of Spirit: dialektika Hegel bukan triad: tesis - antitesis - tetapi lebih sebagai sistem dual. Setiap "tesis" "antitesisnya", dan yang nampak sebagai sintesis dari antitesis sebelumnya.

The disparity which exist in consciousness between the 'I' and the substance which is its object is the distinction between them, the negative in general. This can be regarded as the defect of both, though it is their soul, or that which moves them. That is why some of the ancients conceive the void as the principle of motion, for they rightly saw the moving principle as the negative, though they did not as yet grasp that the negative is the self. Now, although this negative appears at first as a disparity between the 'I' and its object, it is just as much the disparity of the substance with itself. Those what seems to happen outside of it, to be an activity directed, against it, is really its own doing, and Substance shows itself to be essentially Subject. When it has shown this completely, Spirit has made its existence identical with its essence: it has itselffor its object just as it is, and the abstract element of immediacy, and of the separation of knowing and truth, is overcome. Being is then absolutely mediated... (Hegel, 1977, 21).

(Disparitas yang ada dalam kesadaran antara "Aku" dan substansi yang adalah objeknya, merupakan distingsi antara mereka, negasi dalam keseluruhan. Ini dapat dipandang sebagai cacat dari keduanya, meskipun itu adalah jiwa mereka, atau itu yang menggerakkan mereka. Itu adalah mengapa beberapa orang kuno memahami kehampaan sebagai prinsip gerak, mereka benar melihat prinsip gerak sebagai negasi, meskipun mereka belum memahami bahwa negasi adalah kedirian. Seka- 
rang meskipun negasi ini nampak pada awalnya sebagai sebuah disparitas antara "Aku" dan objeknya, hal itu seperti banyak disparitas seperti substansi dengan dirinya sendiri. Jadi apa yang tampak terjadi di luar negasi, menjadi sebuah aktivitas ditunjukkan menentang negasi itu, adalah sungguh kerjanya sendiri, dan substansi mengetahui dirinya menjadi subjek esensial. Ketika subjek memperlihatkan kelengkapannya, Roh membuat eksistensi identik dengan esensinya, diri bagi objek seperti dirinya sendiri, dan unsur abstrak kelangsungan serta keterpisahan, mengetahui dan kebenaran, diatasi. Pengada kemudian sepenuhnya diperantarai).

Dialektika adalah sebuah perkembangan yang tidak berhenti. Dan apabila proses negativitas berhenti, dialektika berubah menjadi Skeptisisme.

(W)hen the - Dialectic principle is employed by the understanding separately and independently - especially as seen in its application to philosophical theories Dialectical becomes Skepticism: in which the result that ensues its action is presented as a mere negation... Dialectic is different from 'Reflection'. In the first instance, Reflection is that movement out beyond the isolated predicate of a thing which give it some reference, and brings out its relativity, while still in others respects leaving it its isolated validity. But by Dialectic is meant the indwelling tendency outwards by which the one sideness and limitation of predicates of understanding is seen in its true light, and shown to be the negation of them .... Thus understood the Dialectic principle constitutes the life and soul of scientific progress, by the dynamic which alone gives immanent connection and necessity to body of science. It is highest importance to ascertain and understand rightly the nature of dialectic (Hegel, 1975: 116).

(Ketika prinsip dialektika digunakan oleh akal budi secara terpisah dan independen -teristimewa dilihat dalam aplikasinya pada teori-teori filsafat- Dialektika menjadi Skeptisism: yang mana hasil yang terjadi dari tindakannya dihadirkan sebagai sebuah hal yang sama sekali negasi... Dialektika dibedakan dari 'Refleksi'. Dalam bagian pertama, Reflek- si adalah perkembangan keluar dari isolasi predikat sebuah benda yang memberikan beberapa referensi, dan menghasilkan relativitasnya, sementara masih dalam respek-respek yang lain meninggalkan validitas isolasinya. Tetapi dengan Dialektika berarti tendensi secara permanen hadir keluar melalui sisi yang satu dan membatasi predikat pemahaman dilihat dalam sinar kebenarannya, dan diperlihatkan sebagai negasi bagi mereka... Jadi memahami prinsip Dialektika mengkonstitusikan kehidupan dan jiwa perkembangan ilmiah, dinamika yang memberikan hubungan imanen dan keperluan pada tubuh ilmu pengetahuan. Sangat penting mengetahui dengan pasti dan memahami dengan benar hakikat Dialektika).

\subsection{Metode Penelitian}

Penelitian ini merupakan penelitian historis faktual mengenai konsep intersubjektivitas dalam salah satu karya utama Hegel yaitu Phenomenology of Spirit. Metodologi yang digunakan meliputi penggabungan antara penelitian naskah atau buku dengan penelitian konsep dalam sejarah filsafat. Metodologi yang digunakan meliputi: interpretasi, induksi-deduksi, koherensi intern, holistika, kesinambungan historis, idealisasi, komparasi (Bakker dkk, 1991: 67-71 \& 77-82).

\subsubsection{Interpretasi}

Diusahakan menangkap konsep intersubjektivitas dalam filsafat-filsafat sebelum Hegel. Diusahakan pula menangkap filsafat Hegel. Dan terakhir, diusahakan menangkap setepat mungkin konsep intersubjektivitas dalam Phenomenology.

\subsubsection{Induksi dan deduksi}

Setiap pemakaian konsep intersubjektivitas, filsafat Hegel, dan teks Phenomenology dipelajari sebagai case study.

Dengan mengalisa semua arti dari intersubjektivitas mengikuti segala hubungannya dan membentuk sintesis. Sebaliknya, pemahaman sepenuhnya tentang konsep intersubjektivitas baik dalam tokoh maupun periode, dipergunakan untuk mengartikan secara lebih mudah kasus-kasus khusus. Demikian pula semua konsep dalam Phenomenology, dianalisa satu persatu dan dalam hubungannya satu sama lain dapat 
dibanqun suatu pemahaman sintesis. Dari visi dan gaya menyeluruh yang mendominasi buku ini, dipahami dengan baik detail-detailnya, terutama konsep intersubjektivitas. Di samping itu seluruh karya pikiran Hegel diselidiki melalui induksi dan deduksi, supaya Phenomenology dapat ditentukan tempat yang tepat dalam keseluruhan perkembangan filsafatnya.

\subsubsection{Koherensi Intern}

Dilakukan penyesuaian variasi kosep-kosep satu sama lain secara konsisten, pada masingmasing filsuf. Dilihat aspek-aspek dan konsepkonsep dalam filsafat Hegel menurut keselarasan satu sama lain. Uitetapkan inti pikiran yang mendasar, dan topik-topik sentrai filsafat Hegel. Uilakukan penetapan pikiran-pikiran mendasar dalam Phenomenology. Semua aspek-aspek dan konsep-konsep seperti: kesadaran: kesadarandiri: akal budi: Roh: perkembangan Roh: dll, dilihat menurut keselarasannya satu sama lain. Dilakukan penetapan konsep intersubjektivitas, diteliti susunan logis sistematis konsep itu, dipersiskan gaya dan metode pengarang dalam menguraikan konsep itu.

\subsubsection{Holistika}

Dilihat konsep intersubjektivitas dalam Phenomenology. Konsep itu dilihat dalam rangka keseluruhan visi mengenai manusia, dunia dan Tuhan.

\subsubsection{Kesinambungan Historis}

Konsep intersubjektivitas pertama-tama dilihat dari, konteks penggunaannya pada beberapa filsuf dari jaman Yunanf sampai Hegel. Diikuti interpretasi dan reaksi mereka terhadap filsuffilsuf sebelumnya. Diteliti kesinambungan pemikiran dari filsuf-filsut tersebut, dan dibuat analisis peralihan dari filsuf yang satu.

Konsep intersubjektivitas tanpa melepaskan latar belakang Latar belakang eksternal meliputi: jaman, situasi sosialekonomi, politik, kebudayaan, dunia sastra dan filsafat. Sedangkan latar belakang internal meliputi: riwayat hidup Hegel, pendidikannya, pengaruh yang diterimanya, relasi dengan filsuf-filsuf sejamannya dan segala macam pengalaman yang membentuk kesadarannya.

Begitu juga diperhatikan perkembangan intern pada Hegel. Tahap-tahap dalam pikirannya, dan perubahan dalam minat atau arah filsafat- nya. Ide tentang intersubjektivitas dan konsepkonsep lainnya yang tercantum dalam Phenomenology dibandingkan dengan karya-karya yang lebih dahulu dan yang kemudian. Lebih luas dari itu, konsepsi intersubjektivitas Hegel diterjemahkan dalam terminologi dan pemahaman yang sesuai dengan cara berpikir aktual sekarang.

\subsubsection{Idealisasi}

Dicari konsep intersubjektivitas yang sebenarnya dikatakan Hegel, sehingga diperoleh konsep yang seuniversal dan seideal mungkin.

\subsubsection{Komparasi}

Komparasi diadakan di antara pemikiran-pemikiran konsep intersubjektivitas. Dibandingkan kesamaan serta perbedaan arti dan pemakaian konsep intersubjektivitas. Dipersiskan isi konsep intersubjektivitas dari Hegel.

Isi Phenomenology dibandingkan dengan buku-buku lain baik karya Hegel maupun karya filsuf lain. Dalam perbandingan itu diperhatikan keseluruhan pikiran denqan ideide pokok, kedudukan konsep-konsep, metode dll.

Konsep intersubjektivitas dalam Phenomenology dibandingkan dengan konsep intersubjektivitas dari karya-karya Hegel yang lain. Dibandingkan konsep intersubjektivitas Hegel dengan seluruh perkembangan konsep intersubjektivitas sebelum Hegel.

\section{PEMBAHASAN}

Konsep Intersubjektivitas Hegel merupakan konsep yang berproses dan selalu diperbaharui sejak awal perkembangan pemikirannya. Oleh karena itu, dalam bagian ini, dilihat tahap-tahap pembentukan konsep intersubjektivitas: pertama, dari masa Hegel muda dalam karyanya semasa di Jena yaitu: Philosophy of Mind. Kedua dalam Phenomenology of Spirit, dan ketiga diteliti dalam Philosophy of Right. Tetapi terlebih dahulu diteliti posisi filsafat Hegel yang berkaitan dengan modernitas.

\subsection{Hegel dan kritik atas modernitas}

Hal ini mungkin tampak aneh membicarakan Hegel sebagai seorang pengkritik jaman modern. Tetapi dalam bukunya yang berjudul Philosophical Discourse of Modernity, Habermas (1987, 4-30) mendiskripsikan dan membukti- 
kan bahwa Hegel adalah filsuf pertama yang membangun konsep modernitas secara jelas. Oleh karena itu, dengan mengikuti argumen Habermas tersebut, dalam membicarakan konsep modernitas harus kembali kepada Hegel jika membutuhkan memahami hubungan internal anlara modernitas dan rasionalitas.

Hegel menggunakan konsep modernitas pertama-tama dalam konteks historis, sebagai konsep jaman: "Abad baru" adalah "abad modern". Ini berkaitan dengan penemuan 'dunia baru', $R e$ naissance dan Reformasi, yang merupakan tiga kejadian momumental sekitar 1500 mewujudkan masa ambang antara jaman modern dan abad pertengahan. Hegel (1956: 912), dalam Lectures on Philosophy of History menggunakan sebutan untuk mengklasifikasikan dunia Kristen Jerman keluar dari jaman Romawi dan Yunani kuno. Pembagian masih digunakan, sekarang menjadi Periode Modern, Abad Pertengahan dan Jaman Purbakala (sejarah modern, pertengahan dan kuno), dapat mengambil bentuk seperti itu hanya setelah. ungkapan "baru" atau "abad modern".

Habermas mengatakan bahwa Hegel merupakan filsuf yang pertama kali memunculkan sampai tingkat filosofis masalah proses pemisahan modernitas dari norma-norma yang terbentang di luar diri subjek. Secara pasti, dalam arti kritik atas tradisi yang mengintegrasikan pengalaman Reformasi dan Renaissance dengan reaksi awal ilmu pengetahuan alam modern, serta filsafat modern dari Skolastisme akhir sampai Kant telah mengungkapkan pemahaman diri tentang modernitas. Tetapi hanya pada akhir abad delapan belas problem kepastian-diri (self-assurance) dari modernitas tampil ke muka dalam cara yang oleh Hegel ditangkap sebagai persoalan filsafat, dan sungguh sebagai persoalan fundamental dalam filsafatnya. Hegel melihat filsafat dikonfrontasikan dengan tugas yang dipegang pada jamannya, yaitu kebutuhan pemastian diri bagi kecemasan yang disebabkan oleh fakta keberadaan modernitas tanpa modelmodel yang menstabilkan dirinya sendiri pada basis bagian-bagiannya. Hegel memperlihatkan ia tidak dapat menghasilkan konsep filsafat yang lepas dari konsep filosofis modernitas.

Bagi Hegel, abad modern dibentuk secara universal oleh struktur hubungan diri yang la sebut subjektivitas:
The principle of modern world is freedom of subjectivity, the principle that all the essential factors present in the intellectual whole are now coming into their right in the course of their development. Starting from this point of view, we can hardly raise the idle question: Which is better from of government monarchy or democracy? We may only say that all constitutional forms are one-sided unless they can sustain in themselves the principle of free subjectivity and know how to correspond with a matured rationality (Hegel, 1967: 286).

(Prinsip dunia modern adalah 'pembebasan subjektivitas', prinsip yang mana semua faktor esensial hadir dalam keseluruhan intelektual sekarang datang pada kebenaran mereka dalam arti perkembangan merekbi mulai dari sudut pandang ini, kita dapat kesulitan memunculkan pertanyaan yang tidak berarti: Mana yang lebih baik antara monarki dan demokrasi ? Kita hanya boleh mengatakan bahwa semua bentuk konstitusional adalah bersisi-satu kecuali kalau mereka dapat menyinambungkan dalam diri mereka prinsip subjektivitas Yang bebas dan memahami bagaimana berkaitan dengan rasionalitas yang dewasa).

Ketika melukiskan ilmu filsafat dari abad modern, Hegel menjelaskan "subjektivitas" dari arti "kebebasan" dan "refleksi":

The principle is hereby gained, but only the principle of freedom of spirit: and the greatness of our time rest in the fact of that freedom, the peculiar possession of mind whereby it is at home with it-self in itself, is recognized, and that mind has this consciousness within itself (Hegel, 1968: Vol. III: 923)

(Prinsip yang dengan ini diperoleh, tetapi hanya prinsip kebebasan roh: dan yang terbesar dari abad kita berhenti dalam fakta bahwa kebebasan, teristimewa milik pikiran dengan jalan mana hal itu kerasan dengan dirinya sendiri, diakui, dan bahwa pikiran memiliki kesadaran bersama dirinya sendiri).

Kunci kejadian-kejadian sejarah yang memapankan prinsip subjektivitas adalah Reformasi, Enlightenment, dan Revolusi 
Perancis. Bersama Luther, keyakinan agama menjadi reflektif: dunia ketuhanan diubah ke dalam perhatian subjektivitas yang ditempatkan oleh dirinya sendiri. Menantang keyakinan dalam otoritas ajaran dan tradisi gereja. Protestanisme menyetujui otoritas subjek mengandalkan diri pada pengertiannya sendiri. Kemudian juga deklarasi hakhak asasi manusia mensahihkan prinsip kebebasan kehendak menentang pra pengada hukum yang secara historis merupakan basis substantif negara.

Lebih lanjut, interpretasi Habermas atas Hegel memperlihatkan bahwa menurut Hegel prinsip subjektivitas menetukan bentuk kebudayaan modern. Ini dipegang secara pasti pertama-tama untuk kepentingan ilmu pengetahuan. Kemudian pada wilayah moral, konsep moral jaman modern diikuti dari pengakuan kebebasan subjektif individu-individu. Pada satu sisi, mereka menemukan hak individu mencapai apa yang mereka duga dikerjakan secara sahih, dan pada sisi yang lain, mereka menemukan tuntutan bahwa setiap person boleh mengejar tujuan kesejahteraan pribadinya hanya dalam harmoni dengan jahteraan setiap orang lain.

Kehendak subjektif mencapai otonomi di bawah hukum universal, tetapi pencapaian itu hanya dalam kebebasan kehendak subjektif atau secara implisit prinsip-prinsip kehendak dapat diaktualisasikan. Struktur kehendak subjektif ini dipahami dalam filsafat sebagai subjektivitas abstrak, dalam pengertian "cogito ergo sum"-nya Descartes dan "Aku transendetal" dalam filsafat Kant.

Hegel meyakinkan bahwa abad Pencerahan berpuncak pada Kant dan Fichte, menegakkan sebuah berhala dalam pikiran. Hal ini secara salah menanamkan Akal-Budi (Understanding) atau refleksi dalam tempat Rasio (Reason) dan meninggikan yang terbatas pada status tak terbatas. Unsur-unsur tak terbatas filsafat refleksi dalam kebenaran diperoleh Akal-Budi, unsur rasional yang melemahkan sendiri dalam negasi keterbatasan.

Sebagaimana tampak bagi Hegel muda, positivitas kehidupan etis merupakan cap dari jaman Hegel. Ia menerapkan kata "positif" bagi agama-agama yang didasarkan pada otoritas menyendiri dan tidak menggabungkan nilai-nilai kemanusiaan ke dalam moralitas mereka. "Positif" mengaplikasikan resep sesuai dengan yang diyakini, yang diduga mampu menghadir- kan rahmat Tuhan melalui kerja, hal itu sungguh -sungguh tindakan moral. Dalam agama "positif" terjadi pemisahan doktrin agama dari kehidupan dan pemilikan bersama, pemisahan pengetahuan pendeta dari pemujaan yang mendalam dalam masyarakat, dan jalan memutar yang diduga mampu mengarahkan moralitas hanya melalui otoritas dan perbuatan menajubkan dari seorang pribadi: ke jaminan legalitas tindakan, dan akhirnya, di atas semua itu, pemisahan agama pribadi dari kehidupan publik adalah "positif".

Dalam awal karyanya, menurut Habermas, Hegel mengusahakan rasio sebagai rekonsiliasi. Ia selalu menekankan sisi otoritas kesadaran-diri (self-consciousness), ketika pikiran menghasilkan pembagian melalui refleksi. Manifestasi modern "yang positif" membuka kedok prinsip subjektivitas sebagai dominasi tunggal. Hegel menentang pengetahuan secara sewenangwenang dari rasio yang memusat pada subjek (subject-centered reason). Ia menyimpulkan kekuatan penyatuan dari intersubjektivitas yang tampak di bawah judul "cinta" dan "kehidupan". Tempat hubungan reflektif di antara subjek dan objek ditempatkan melalui perantaraan komunikasi subjek-subjek. Roh kehidupan (living spirit) merupakan wahana menemukan komunalitas secara langsung. Dalam komunalitas ini, seorang subjek dapat memiliki dirinya sendiri dan menjadi seorang subjek bersama subjek lain, sementara masih tetap merupakan dirinya sendiri. Isolasi subjek sebagai gangguan komunikasi kemudian dihimpun dan diubah menjadi gerakan dinamis yang inheren dalam tujuan yaitu memapankan kembali intersubjektivitas.

\subsection{Konsep Intersubjektivitas dari Hegel Muda}

Karya Hegel: Philosophy of Mind dari periode Jena, diteliti berdasarkan penafsiran atas karya tersebut oleh: Herbert Marcuse dan Jurgen Habermas.

\subsubsection{Penafsiran Herbert Marcuse}

Dalam Reason and Revolution, Marcuse (1969: 74-77) menafsirkan pemikiran Hegel tentang filsafat Roh yang dikerjakan Hegel pada masa di Jena. Ia bertolak dari tiga kategori pendasaran integrasi masyarakat, yaitu: bahasa, kerja dan barang milik. Menurut Marcuse tiga kategori itu mendasari tiga bentuk komunitas yang berbeda, 
yaitu keluarga, civil society dan negara. Ketika bentuk masyarakat itu kemudian dikembangkan oleh Hegel secara mendetail dalam Philosophy of Right.

Sejarah dunia manusia tidak dimulai dengan perjuangan individu dalam alam, tetapi komunitaslah yang datang pertama. Kesadaran manusia dalam komunitas yang pertama ini merupakan komuniawal ini mengatetapi kesadaran universal (Roh), barangkali dapat digambarkan sebagai kesadaran kelompok primitif di mana semua individu menjadi dibawahkan ke dalam komunitas. Inilah yang oleh Hegel dikategorikan sebagai keluarga. Dunia berkembang, dalam rangkaian integrasi dari pertentanganan-pertentangan. Bentuk kesadaran dalam komunitas yang kedua: individu menyadari subjektivitasnya. Pada tahap ini terjadi konflik antar mereka. Masyarakat atomistik ini disebut civil society dan pada tahap terakhir, mereka nampak sebagai bangsa.

Bahasa adalah medium dari integrasi komunitas. Dalam bentuk komunitas keluarga, bahasa merupakan medium pertama dari individuasi. Individu, melalui hal itu, memperoleh penguasaan atas objek-objek dan memberi nama. Seorang manusia mampu mengetahui dan mengawasi batas-batas perannya di antara individuindividu dalam kelompok komunitas orang lain. Tetapi bahasa juga memungkinkan individu menyadari secara otonom, melawan rekan demi keinginan dan kebutuhannya. Oleh karena itu, bahasa di sini berperan sebagai medium masyarakat tahap kedua, civil society. Sedangkan bahasa sebagai landasan integrasi negara merupakan sintesa antara bahasa universal yang bersifat langsung dan bahasa yang mengkerangkai kesadaran subjektif.

Selain bahasa, kerja juga merupakan medium integrasi komunitas. Kerja di sini dipahami sebagai usaha manusia mengolah alam, manusia sebagai subjek dan alam sebagai objek. Sedangkan sebagai landasan integrasi hubungan antar manusia, kerja dipahami sebagai hasil kerja yaitu barang milik. Kerja, pertama-tama menyatukan individu-individu ke dalam keluarga. Di dalam kerja, keluarga, "barang milik" keluarga ditetapkan untuk subsistensi. Barang milik keluarga berdiri di antara milik keluarga lain. Konflik muncul di sini bukan sebagai kesadaran sebagai hasil pembentukan bahasa, tetapi hasil perebutan harta milik antar kelompok. Institusionalisa- si harta milik pribadi memaknakan, bahwa "objek-objek" akhirnya digabungkan ke dalam dunia subjektif: "objek-objek tidak sekedar benda mati", tetapi termasuk totalitas mereka, pada wilayah realisasi diri subjek. Semua perjuangan sejarah menjadi perjuangan antara kelompok individu-individu pemilik harta kekayaan. Kerja dilihat sebagai unsur yang esensial dan konstitutif dari individualitas, individu melindungi dan mempertahankan harta kekayaan agar mempertahankan dirinya sebagai individu. Konsekuensinya, perjuangan hidup dan mati. Inilah prototipe civil society. Pertentangan hanya dapat diintegrasikan ke dalam bentuk komunitas bangsa.

Marcuse memperlihatkan bahwa situasi konfik didamaikan dalam perjuangan hidup dan mati mewujud dalam perjuangan untuk pengakuan (struggle for recognition). Kesadaran mencapai integrasi sekali lagi sebagai roh rakyat, tetapi kesatuannya tidak sekedar langsung dan primitif. Di sini Hegel menyebut kesatuan term perantaraan bagi intersubjektivitas. Aktivitas perantaraan ini adalah aktivitas kerja. Melalui kerja, manusia mengatasi keterasingan antara dunia objektif dan dunia subjektif: dia mentransformasikan alam menjadi medium yang pantas bagi perkembangan diri. Melalui kerja, manusia kehilangan eksistensi atomiknya. Dari seorang individu yang dipertentangkan dengan semua individu lain, menjadi seorang anggota komunitas. Individu melalui kebajikan kerjanya, berubah menjadi universal. Kerja pada hakekatnya adalah aktivitas universal, produknya dapat dipertukarkan di antara semua individu.

Marcuse (1969: 80-86), dalam menafsirkan Jenenser Realphilosoohie II, mendeskripsikan kritik Hegel atas masyarakat modern. Menurut Hegel, transisi dari keluarga ke bangsa memiliki kesamaan secara kasar dengan transisi dari "keadaan alami" (state of nature) ke civil society. Hegel berpendapat civil society, digambarkan dalam Revolusi Perancis, mengandung prinsipprinsip di luar batas yang diberikan kerangka kerja masyarakat individualis. Ide-ide tentang rasio dan kebebasan, merupakan nilai-nilai yang tidak dapat dikorbankan kepada negara. Hegel berjuang sepanjang hidupnya membuat rasio dan kebebasan sesuai dengan kebutuhan akan "pengkontrolan dan pengekangan". Bermacammacam usaha Hegel dalam memecahkan persoalan itu. Hasil akhirnya: negara rasional di bawah 
aturan hukum.

Hegel, sebagaimana dikutip oleh Marcuse (1969: 81), dalam Jenenser Realahilosophie II, melihat keanarkian dan kekaburan civil society dengan warna suram.

(The individual) is subject to the complete confusion and hazard of the whole. A mass of population is condemned to stupefying, unhealthy and insecure labor factories, manufactures, mines, and so on. Whole branches of industry which supported a large bulk of the population suddenly fold up because the mode of changes or because the values of their product fall on account of new inventions in their countries, or for other reasons. Whole masses are thus abandoned to helpless poverty. The conflict between vast wealth and vast poverty steps forth, a poverty unable to improve its condition. Wealth becomes.... a predominant power. Its accumulation takes place party by chance, partly through general mode or distribution.... Acquisition develops into a many-sided system which ramifies into field from which smaller business cannot profit. The utmost abstractness of labor reaches into the most individual types of work and continues to widen its sphere. This inequality of wealth and poverty, this need and necessity turn into the utmost dismemberment of will, inner rebellion and hatred.

(Individu adalah subjek terhadap kekaburan dan resiko selengkapnya dari keseluruhan. Sebuah massa populasi dihukum dengan terbius, tak sehat, dan kerja yang tak aman di pabrik-pabrik, industri-industri, tambangtambang dll. Keseluruhan cabang industri didukung oleh sebuah bagian terbesar populasi yang tiba-tiba gulung tikar karena perubahan mode atau karena nilainilai dari -produk mereka jatuh di atas hitungan investasi-investasi baru di negara lain, atau banyak lagi alasan lain. Seluruh massa dibuang menjadi kaum miskin yang tak berdaya. Konflik antara sedikit orang kaya dan sangat banyak orang miskin terus berlanjut, kaum miskin tak mampu mengubah kondisinya. Kaum kaya menjadi penguasa utama. Akumulasinya mengambil tempat sebagian melalui kesempatan, sebagian melalui distribusi secara menyeluruh. Keahlian berkembang menjadi sebuah sistem dengan banyak- sisi bercabang-cabang menjadi wilayahwilayah bisnis di mana bisnis yang lebih kecil menjadi tidak menguntungkan. Abstraksi kerja sepenuhnya mencapai tipe kerja yang sangat individual dan wilayahnya terus melebar. Kesenjangan antara kaum kaya dan miskin berubah menjadi pemotongan bagianbagian dari kehendak masing-masing, pemberontakan dan kebencian batin).

Resiko dalam masyarakat industri bukan semata-mata kebetulan, melainkan berproses. Individu-individu memproduksi eksistensi melalui hubungan pertukaran dalam pasar memberikan integrasi yang dibutuhkan. Individuindividu yang diisolasi akan bertempur dalam konilik yang kompetitif. Perjuangan individu yang dahsyat dalam masyarakat industri atau masyarakat-pemroduksi komoditi (comodity producing-society) lebih "baik" dibandingkan konflik antar kelompok yang saling berebut harta milik. Hubungan pertukaran dalam pasar meletakkan dalam tingkat perkembangan sejarah yang lebih tinggi dan mengimplikasikan sebuah "pengakuan timbal balik" dari hak-hak individual. Kontrak mengekspresikan pengakuan ini sebagai realitas sosial.

Marcuse memperlihatkan bahwa bagi Hegel muda konsep intersubjektivitas dalam civil society adalah kontrak. Kontrak merupakan salah satu pondasi masyarakat modern, masyarakat secara aktual sebuah kerangka kerja dari kontrak-kontrak antar individu. Dalam kontrak mensyaratkan hubungan timbal balik yang diperhitungkan dan rasional. Oleh karena itu, "universal adalah substansi kontrak". Tetapi dalam kontrak, situasi identitas antara partikular dan universal belum direalisasikan. Potensi-potensi individu jauh dari terlindungi dalam civil society. Konsekuensinya, kekuasaan harus berdiri di belakang setiap kontrak. Hal itu memungkinkan terjadi tindak kejahatan dan pemberontakan. Pengakuan aturan hukum adalah tahap integrasi dari situasi ini, di mana individu mendamaikan diri dengan masyarakat. Aturan hukum dibedakan dari aturan kontrak sejauh hal itu ditempatkan ke dalam perhitungan "diri individu dalam eksistensinya sebaik dalam pengetahuannya". Individu mengetahui bahwa dia dapat eksis hanya melalui hukum, bukan hanya karena hal itu melindungi dia, tetapi hal itu jaminan utama bagi perkembangan diri. Dalam tahap ini intersub- 
jektivitas berlandaskan hukum.

Hegel menggambarkan bangsa sebagai masyarakat demokratis. Hal itu diperlihatkan oleh situasi negara-kota Yunani. Di sana, kesatuan antara individu dan kehendak umum masih spontan dan secara kebetulan saja. Tetapi demokrasi semacam ini masih rapuh. Integrasi bangsa Yunani hanya dalam kesatuan langsung, didasarkan atas perasaan belaka dan tidak atas kesadaran intelektual dan organisasi moral masyarakat: Hegel mengatakan bahwa situasi itu membutuhkan penjaga kesatuan yang baik yaitu: monarki. Negara dalam bentuk monarki adalah organisasi rasional dari masyarakat dalam beragam peranan. Semua peran seluruhnya diabdikan untuk kepentingan umum.

Lebih penting lagi, negara monarki merupakan negara Kristen. Lebih tepat lagi, negara Kristen yang datang bersama Reformasi Jerman. Baginya, negara adalah perwujudan dari prinsip-prinsip kebebasan Kristiani. Kebebasan ini memproklamasikan kemerdekaan hati nurani manusia, dan kedudukan umat manusia sederajat di hadapan Tuhan. Menurut Hegel, tanpa kebebasan batin ini, kesadaran akan demokrasi berada di luar batin manusia. Kesadaran semacam ini tidak berfaedah. Reformasi Protestan menggambarkan prestasi terbesar dalam sejarah yaitu: keputusan bahwa individu sungguhsungguh bebas hanya ketika ia menjadi kesadaran-diri. Kesadaran-diri ini tidak dapat dicabut. Protestanisme memapankan konsep kesadaran-diri ini dengan memperlihatkan bahwa kemerdekaan Kristiani diimplikasikan ke dalam wilayah realitas sosial, kepatuhan dan ketaatan kepada hirarki ketuhanan yang maujud dalam negara.

Jadi, dalam konsep negara sebagai komunitas bangsa, intersubjektivitas berdasarkan kesadaran sebagai bentukan universal (Roh). Kesadaran ini bersifat langsung seperti yang digambarkan negara-kota Yunani. Tetapi sekaligus Roh mendasari subjektivitas manusia sebagai kesadaran-diri. Dengan demikian, intersubjektivitas bersifat langsung sebagai ungkapan kesadaran-diri manusia bebas.

\subsubsection{Penafsiran Jurgen Habermas}

Habermas dalam bukunya: Technik und wissenchaft als Ideologi (1990: 1- 31) dan juga Theory and Practice (1974: 192-169), menafsirkan kembali karya-karya Hegel muda dalam bab berjudul: "Kerja dan Interaksi: Catatan-catatan tentang Karya Hegel di Jena, filsafat tentang Roh", menafsirkan konsep intersubjektivitas Hegel Muda secara berbeda dari Marcuse. Ia bertolak dari kategori-kategori: bahasa, alat dan keluarga, menunjuk dalam hubungan dialektis yang ekuivalen: representasi simbolis, proses kerja dan interaksi.

Terhadap tiga hubungan kerja, bahasa, dan interaksi, Habermas (1990: 2) mengemukakan tesis:

"Bukanlah Roh dalam gerak absolut merefleksikan dirinya, antara lain memanifestasikan diri dalam bahasa, kerja dan hubungan etis, melainkan pengertian Roh baru ditentukan oleh saling hubungan yang dialektis antara perlambang bahasa, kerja dan interaksi."

Roh yang dimaksudkan Hegel di sini dalam arti suatu kesatuan antara inteligensi dan kehendak. Kesatuan ini dibentuk dalam jalinan hubungan yang fundamental antara representasi-simbolis, kerja dan interaksi. Hubungan antara ketiga momen itu bukan dalam abstraksi-abstraksi. Dalam abstraksi-abstraksi, Roh hanyalah roh subjektif dan objektifikasiobjektifikasi sebagai tempat Roh memperoleh eksistensi lahirnya dikeluarkan dari proses Roh.

Berdasar konsep Roh ini Habermas memahami konsep subjektivitas dari Hegel secara baru. Pengertian Aku, menurut Hegel, mencakup pengalaman dasar mengenai dialektika. Aku digambarkan sebagai kesatuan. Suatu "kesatuan yang mengacu pada dirinya sendiri", sebagai "Aku berpikir", harus dapat menyertai semua pikiran saya. Konsep ini mengartikulasikan pengalaman dasar darifilsafat refleksi: yakni, pengalaman identitas Aku di dalam refleksi-diri, jadi pengalaman-diri dari subjek yang mengenal, melepaskan diri dari segala objek yang mungkin di dunia dan mengacu kembali kepada diri sendiri sebagai satu-satunya objek. Tetapi Hegel lebih lanjut mengikuti Dialektika Aku dan orang lain dalam rangka subjektivitas roh, di mana Aku yang berkomunikasi bukan Aku dengan dirinya sendiri sebagai diri yang lain, melainkan Aku dengan suatu Aku lain sebagai orang lain.

Dialektika kesadaran-diri, menurut Hegel, melampaui hubungan refleksi-diri dan merupakan hubungan komplementer antara individu-individu yang saling mengenal. Pengalaman 
kesadaran-diri tidak lagi merupakan pengalaman asali, melainkan lebih merupakan hasil pengalaman interaksi, di mana Aku belajar melihat diri dengan mata subjek lain...Dalam dialektika ini, Roh bukan dalam arti dasar yang melandasi subjektivitas diri dalam kesadaran-diri, melainkan merupakan medium yang di dalamnya suatu Aku berkomunikasi dengan Aku lain itu. Kedua Aku itu baru berkembang atas dasar resiprositas itu dan menjadi subjek.

Aku sebagai kesadaran-diri oleh Hegel dipahami Aku kosong seperti diajarkan Kant, tetapi la menurunkan tingkat Aku itu menjadi momen, dengan Jalan memasukkannya ke dalam kategori yang umum. Aku sebagai kesadaran-diri adalah Aku yang umum, karena ia merupakan Aku yang abstrak, yakni sebagai hasil abstraksi dari segala Isi, Aku bagi suatu subyek yang mengenal atau membayangkan sudah diberikan. Tetapi Aku juga kategori keindividualan. Aku adalah individualitas, tidak hanya dalam arti pengidentifikasian yang dapat diulang-ulang dari seseorang tertentu di dalam rangka koordinatkoordinat yang dapat ditunjukkan, melainkan dalam arti suatu nama diri yang mengacu kepada sembarang orang yang diindividukan. Aku adalah Umum dan Individu tercakup menjadi satu. Roh adalah perkembangan dialektis dari kesatuan ini, yakni totalitas etis.

Menurut Hegel, Roh (Spirit) tidak sekedar "Roh Bangsa": suatu jaman: atau sebuah tim, melainkan komunikasi individu-individu di dalam suatu medium umum. Hubungan Roh dengan individu-individu itu, seperti hubungan antara gramatika suatu bahasa dengan orangorang yang berbicara dalam bahasa itu. Atau, antara suatu sistem norma yang berlaku dengan individu-individu yang berbuat. Jadi di dalam hubungan antara Roh dan individu tidak ditonjolkan momen yang umum terhadap yang khas. Keorisinalan pemahaman Hegel itu adalah: Aku sebagai kesadaran diri hanya dapat dimengerti jika ia merupakan Roh, artinya, apabila Aku dari subjektivitas berubah menjadi objektivitas yang umum. Dalam yang umum itu, atas dasar resiprositas, subjek-subjek saling mengenal diri masing-masing. Dengan demikian, subjek-subjek yang tidak identik satu sama lain, dipersatukan. Dalam hal ini, sosialisasi sebenarnya tidak boleh diartikan sebagai pemasyarakatan suatu individu tertentu, lebih tepat jika dikatakan, bahwa sosialisasi baru menghasilkan manusia yang diindividukan.

Hegel merekonstruksi penindasan dan pemulihan situasi dialog sebagai hubungan etis. Di dalam gerak ini, yang hanya bisa dinamakan dialektis, hubungan-hubungan logis dari suatu komunikasi yang didistorsikan dengan menggunakan kekerasan pada gilirannya akan melakukan kekerasan praktis. Kekerasan baru ditiadakan ketika situasi dialog sudah tercapai. Hilangnya kekerasan melahirkan kebebasan. Oleh karena itu, pengenalan diri orang lain yang dialogis atau cinta kasih merupakan rekonsiliasi. Yang dialektis bukan intersubjektivitas tanpa paksaan itu melainkan proses represinya dan pemulihannya.

Dalam hubungan tentang pemilikan, Hegel menunjukkan subjek-subjek yang sedang berjuang dengan segenap jiwa raga mereka mempertahankan setiap milik mereka yang mereka peroleh melalui kerja. Subjek-subjek berjuang untuk memperoleh pengakuan. Perjuangan ini merupakan perjuangan hidup dan mati. Hasil hubungan ini bukan pengenalan-diri yang langsung dalam diri yang lainnya, melainkan suatu keadaan di mana subjek-subjek berhadapan satu sama lain atas dasar pengakuan timbal balik. Dikatakan timbal balik sebab berdasarkan kesadaran bahwa identitas Aku hanya mungkin melalui identitas orang lain yang mengakui Aku, dan yang pada gilirannya tergantung pengakuanku.

Hegel memahami konsepsi Aku dari proses perkembangan, yakni dari proses perkembangan penyatuan komunikatif dari subjek-subjek yang saling berhadapan. Di dalam kuliah-kuliahnya di Jena, Hegel mengkonstruksi dengan menggunakan contoh kehidupan bersama suatu kelompok primer, yakni interaksi dalam lingkungan keluarga. Konsepsi "milik keluarga" sebagai titik pusat yang berlaku bagi hubungan timbal balik. Dua kategori lain: bahasa dan kerja. Disamping Keluarga, oleh Hegel-dikembangkan pula dua kategori lain: kerja dan bahasa. Ketiga model dasar itu heterogen, bahasd dan kerja sebagai medium-medium Roh tidak dapat diasalkan dari pengalaman interaksi dan pengakuan timbal balik.

Bahasa bagi Hegel tidak hanya mencakup hubungan antara subjek yang bertindak dan kehidupan bersama, melainkan juga berarti penggunaan simbol-simbol oleh individu yang menyendiri, yang dihadapkan pada alam dan yang 
memberi nama pada benda-benda. Hegel memandang representasi sebagai fungsi sebenarnya dari simbol-simbol: sintetis asali keaneka ragaman berkaitan dengan fungsi representasi tanda-tanda, yang memungkinkan pengidentfikasian bendabenda. Melalui simbol-simbol itu, kesadaran yang berbicara menjadi objektif bagi dirinya sendiri sebagai suatu subjek. Oleh karena itu, bahasa memberikan pemaknaan ganda: di satu pihak, melebur dan menyimpan benda yang dilihat di dalam sebuah simbol yang merepresentasikan benda itu. Dan di lain pihak, memelihara jarak antara kesadaran dan objekobjeknya, di mana Aku melalui simbol-simbol ini yang diciptakannya sendiri, dalam waktu bersamaan berada dalam benda-benda itu dan pada dirinya sendiri. Dalam bahasa, Roh adalah logos sebuah dunia dan bukan refleksi kesadaran-diri yang menyendiri.

Sedangkan kerja dipahami Hegel sebagai cara spesifik memuaskan dorongan. Kerja mematahkan pendiktean nafsu yang langsung dan seolaholah menahan proses pemuasan dorongan ini. Alat-alat kerja di dalamnya mengendap generalisasikan dari Alat kerja mengikat merupakan titik pusat bidang kerja, pengalaman-pengalaman yang sudah diorang yang bekerja dengan objeknya. aturan-aturan yang tetap, dengan penguasaan proses-proses alam dapat diulangi sesuka hati. Di dalam alat kerja, subjektivitas kerja diangkat menjadi umum: setiap orang dapat membuat tiruannya dan melakukan pekerjaan yang sama. Dilihat dari segi ini, kerja merupakan aturan yang tetap.

Pada mulanya bukan alam yang ditundukkan dengan simbol-simbol ciptaan sendiri, melainkan sebaliknya, subjeklah yang tunduk kepada kekuatan alam. Tetapi melalui kerja sekarang kesadaran sebagai kesadaran yang bersiasat, yang dalam tindakan-tindakan instrumentalnya menggunakan pengalaman-pengalamannya dalam proses penundukkan alam itu.

Hegel tidak mereduksi interaksi menjadi kerja, tidak pula mengangkat kerja ke dalam interaksi. Keduanya, sejauh dialektika cinta kasih dan perjuangan tidak dapat di atasi oleh hasil-hasil tindakan instrumental dan pengkonstitusian kesadaran yang bersiasat. Hasil pembebasan melalui kerja masuk ke dalam norma-norma, yang mengatur tindakan komplementer manusia.

\subsection{Konsep Intersubjektivitas dalam Phenomenology of Spirit}

Hegel menggambarkan konsep intersubjektivitas dengan bertolak pada ide tentang kesadaran. Hegel mengatakan:

Self-consciousness exist in and for itself when, and by the fact that, it so exist for another: that is, it exist only in acknowledged (Hegel, 1977: 111). Each is for the other the middle term, through which each mediates itself with itself and unites with itself, and each is for itself, and for the other, animmediate being on its own account, which at the same time is such only through this mediation. They recognize themselves as mutually recognizing one another (Hegel, 1977: 112).

(Kesadaran-diri, ada dalam dan bagi dirinya sendiri ketika dan hanya oleh fakta hal itu ada bagi orang lain, berarti, hal itu ada hanya dalam pengakuan).

(Setiap-kesadaran diri merupakan perantara yang lain, melalui beberapa perantaraan diri sendiri dengan diri sendiri dan kesatuan diri sendiri dengan diri sendiri, dan setiap kesadaran-diri untuk diri sendiri dan untuk diri yang lain sebagai keberadaan diri yang serta merta nyata, yang dalam waktu yang sama ada bagi dirinya sendiri melalui perantaraan ini. Mereka mengakui diri mereka sebagai pengakuan timbal balik setiap satu dengan yang lain).

Pengakuan timbal balik seseorang dengan sesamanya merupakan pandangan yang menarik dari Hegel tentang struktur nyata hubungan ketergantungan dua kelompok manusia. Pandangan Hegel itu dapat dilihat pada salah satu analisa paling gemilang tentang arti sosial budaya pekerjaan manusia. Analisa itu ditemukan dalam Phenomenology of spirit pada fragmen Tuan dan Budak (Lordship and Bondage).

Hegel bertitik tolak dari suatu skenario dasar manusia, yaitu: keadaan konfrontasi hidup dan mati antara dua pribadi yang mau membuktikan diri. Konfrontasi antara mereka berakhir dengan kematian satu pihak. Tetapi bisa juga terjadi bahwa akhirnya yang satu menjadi takut dan menyerah. Dengan demikian menjadi budak si pemenang (Magnis Suseno, 1992 a: 114). 
Hegel mengemukakan bahwa kesadaran atau subyek pengetahuan itu serba tidak jadi, melainkan ada dalam proses pembentukan. Sebagaimana dikatakan Hegel:

The unity of being-for-another and being-foroneself, this universal substance, speaks its universal language in customs and laws of its nation... The laws proclaim what each individual is and does the individual knows them nor only as his universal objective... but equally knows himself in them, and in each of his fellow citizens... Just as this unity exist through me, so it exist through the others too (Hegel, 1977: 351).

The single individual consciousness... Is a solid unshaken trust in which spirit has not, for the individual, resolved itself in its abstract moments, and therefore he is not aware of himself as being a pure individuality on his own account. But once he arrived at this idea, as he must, then this immediate unity... his trust, is lost (Hegel, 1977: 355).

(Kesatuan ada-bagi-diri yang lain dan ada-bagi-diri sendiri, ini substansi universal, dibicarakan sebagai bahasa universal dalam adat istiadat, hukum bangsa...

Hukum itu menyatakan bahwa setiap individu adalah dan berbuat, secara perseorangan mengetahui diri mereka tidak hanya keumuman objektif tetapi dengan sama mengetahui dirinya dalam mereka, dan pada setiap warga negara... sebagaimana kesatuan ini eksis melalui saya, maka itu juga eksis melalui yang lain juga).

(Kesadaran perseorangan yang tunggal... sebuah kepastian solid tak terguncang dimana roh tidak, bagi perorangan, mengubah diri ke momen abstrak, dan oleh sebab itu ia tidak menyadari dirinya sebagai ada secara individual murni dalam perhitungannya sendiri. Tetapi dia sebagai yang tunggal dia mencapai ide ini, la harus, kemudian kesatuan langsung ini... kepastiannya, hilang).

Marcuse (1969: ?7), mengatakan bahwa konsep intersubjektivites yang terwujud dalam dialektika tuan dan budak pada Phenomenology of Spirit ini merupakan penjelasan yang lebih mendetail sebagai kelanjutan konsep "perjuangan untuk pengakuan timbal balik" yang telah dikembangkan Hegel pada masa di Jena.

Sebaliknya Habermas (1990: 32-33), mengatakan bahwa sejak dalam Phenomenology of Spirit, dialektika yang khas antara kerja dan interaksi telah kehilangan posisinya, yang secara sistematis masih dimilikinya dalam kuliah-kuliah di Jena. Hegel sekarang menggantikannya dengan pembagian Roh di dalam ensiklopedinya menurut Roh subjektif, Roh objektif dan Roh absolut. Selanjutnya dalam Encyclopedia yaitu karya lebih lanjut setelah Phenomenology, dialektika kerja dan interaksi sekarang dikonstruksi sebagai hubungan-hubungan riil, yang disubordinasikan: di dalam filsafat tentang Roh subjektif. Kerja sebagai tindakan instrumental pada umumnya, tidak disebut-sebut. Gantinya, sebagai kerja sosial di bawah judul sistem kebutuhan-kebutuhan, Hegel menyebut hal itu sebagai unsur penting dalam perkembangan Roh objektif. Hanya dialektika hubungan etis masih mempertahankan posisinya, baik dalam kuliah-kuliah di Jena maupun dalam Encyclopaedia. Tetapi di dalamnya tidak dikenal lagi dialektika cinta kasih dan perjuangan, melainkan dialektika, yang oleh Hegel dikembangkan sebagai gerak Roh absolut.

\subsection{Konsep Intersubjektivitas dalam Philosophy of Right}

Bagi Hegel hubungan antara individu dan masyarakat dalam dunia modern terungkap melalui tiga' lembaga yaitu: hukum, moralitas dan Tatanan-Sosial Moral yang terkait satu sama lain. Urutan ketiga lembaga itu adalah urutan perealisasian kemerdekaan individu yang semakin konkret. Landasan integrasi masyarakat modern adalah sistem hukum modern, menjadi lebih real dalam suara hati setiap anggota masyarakat, dan mencapai kesempurnaan dalam Tatanan-Sosial Moral (Ethical Life. Sittlichkeit) yang dijamin negara. Magnis-Suseno (1990 b: 107-111) mengatakan bahwa hukum oleh Hegel pertama-tama dibedakan dari moralitas. Hukum adalah eksistensi langsung yang diambil secara langsung contoh utamanya: hak milik pribadi. Pengakuan terhadap milik pribadi sebagai hukum: yaitu hak untuk diakui dan dilindungi, merupakan lingkaran luar dari eksistensi, oleh karena itu hukum semata-mata formal dan ab- 
strak, artinya tidak secara khusus menggerakkan kehendak, pengertian dan maksud.

Moralitas, menurut Hegel, adalah lingkaran kehendak subjektif, mempertahankan diri secara otonom berhadapan dengan seluruh dunia luar. Jika hukum bersifat heteronom atau ketaatan terhadap aturan yang berasal dari luar dan yang bersifat memaksa, sebaliknya, moralftas bersifat otonom. Orang yang bermoral bertekad mengikuti suara hatinya. Atas nama suara hatinya ia berani menentang segala paksaan dari luar. Titik tolak moral adalah subjek. Akan tetapi, menurut Hegel, moralitas pun masih bersifat abstrak, karena moralitas tinggal dalam kebatinan murni dan tidak mengacu pada struktur-struktur obiektif dunia sosial.

Lembaga ketiga yang berupa struktur realitas sosial adalah Tatanan Sosial-Moral. Tatanan-Sosial Moral menurut Hegel, adalah konsep kebebasan yang dibangun menjadl dunia yang tampak dan alam kesadaran-diri. Sebagai dunia yang tampak, Talanan-Sosial Moral maujud dalam tatanan moral objektif, yaitu: kebaikan abstrak dibuat menjadi substansi konkret melalui subjektivitas sebagai bentuk yang tak terbatas. Jadi Tatanan-Sosial Moral memposisikan bersama dirinya sendiri, memisahkan diri dari karakter spesifik. Dengan cara demikian, hal itu menentukan konsep-konsep dan membuat tatanan etika menjadi isi independen yang stabil dan subsisten di atas pandangan subjektif dan jalan pikiran yang tiba-tiba. Pemisahan hukum-hukum dan institusi-institusi yang secara absolut valid. Tatanan etika adalah kebebasan atau kehendak absolut yang objektif. Sebagai hal yang objektif, kekuasaan etika mengatur kehidupan individuindividu. Di dalam kekuasaan individu-individu saling berhubungan sebagai kejadian-kejadian dalam substansi. Kekuasaan itu dalam diri individu digambarkan memiliki penampakkan dan menjadi diaktualisasikan.

Menurut Hegel (1967: 108-109), substansi etika dan hukum-hukum serta kekuasaannya, di satu sisi sebuah objek yang berhadapan secara bertentangan dengan subjek, dan dalam arti ini keduanya merupakan ada (being) yang subsisten. Hal itu adalah otoritas yang absolut dan kekuasaan tanpa batas. Tetapi, di sisi lain, substansi etika bukan suatu yang asing bagi subjek. Sebaliknya, subjek secara langsung menyatu dalam tatanan etika melalui sebuah hubungan sebagai sebuah identitas dibandingkan hubun- gan keyakinan atau kepercayaan. Keyakinan dan kepercayaan muncul dalam refleksi. Hal ini disebabkan refleksi mensyaratkan kekuasaan pembentuk ide dan membuat pemisahan. Hubungan subjek dengan tatanan etika lebih sebagai jiwa kehidupan dari kesadaran-diri aktual. Hubungannya bersifat insight (subjek sadar akan objek secara langsung).

Bidang Tatanan-Sosial Moral pada pokoknya ditentukan oleh tiap lingkup hidup manusia: keluarga, masyarakat umum (civil society) dan negara. Tiga lembaga itu disebut Tatanan-Sosial Moral karena mereka memerlukan adat istiadat, kebiasaan dan hukum, sebagaimana individu harus bertindak sebagai mahluk rasional.

Hegel memahami keluarga sebagai roh etika dalam kealamiahan dan kelangsungan. Kemudian, 'Tatanan-Sosial Moral dipahami sebagai civil society perkumpulan anggota masyarakat, sebagai subs istensi diri. Perkumpulan ini hanya abstrak. Mereka membentuk asosiasi berdasarkan kebutuhan-kebutuhan mereka, melalui sistem legal, yaitu: cara-cara melindungi person dan barang milik dan melalui sebuah organisasi eksternal untuk mencapai partikularitas dan kepentingan-kepentingan bersama. Sedangkan negara, dipahami Hegel sebagai, penyatuan konstitusi Negara di antara tatanan moral universal dan kehidupan publik seperti dalam civil society.

\subsubsection{Keluarga.}

Hegel mendefinisikan keluarga sebagai:

The family, as the immediate substantiality of mind, is specifically characterized by love, which is mind's feeling of its own unity. Hence in a family, one's frame of mind is to have selfconsciousness of one's individuality within this unity as the absolute essence of one self, with the result that one is in it not as an independent person but as a member (Hegel, 1967: 111).

(Keluarga, sebagai substansialitas pikiran langsung, secara spesifik dicirikan oleh cinta, yaitu perasaan pikiran dari kesatuannya sendiri. Jadi dalam sebuah keluarga, kerangka pikir seseorang bersama kesatuan ini sebagai hakekat absolut dari diri seseorang, dengan hasil bahwa seseorang dalam hal itu bukan seorang person yang bebas tetapi anggota komunitas). 
Perwujudan keluarga, menurut Hegel, adalah masyarakat negara-kota Yunani. Individu dalam masyarakat Yunani posisinya di bawah kekuasaan komunitas. Subjeklivitas belum diberi tempat. Sebagai contoh: kasus Socrates. Masyarakat Yunani menempatkan Socrates sebagai bagian dari keteraturan sosial. Sebagai seseorang yang memiliki subjektivitas, Socrates merupakan kekuatan destruktif. Kesadaran subJek dikerangkai himpunan konsep yang tersedia secara umum. Maka sudut pandang Socrates dipandang sebagai suatu hal yang tampak pribadi, eksklusif dan termasuk diskursus politik yang asing bagi jamannya.

Menurut Aristoteles (tak disangsikan sangat ideal), polis-polis Yunani kuno menentukan bentuk hidup di mana suhjektivitas individu adalah subjektivitas warga negara dan sebagian ditentukan oleh peran serta mereka dalam kegiatankegiatan yang diperlukan menopang polis itu. Dalam hal ini kesejahteraan individu (eudaemonia) sebagian dapat ditentukan dengan sumbangan yang diberikan individu untuk kesejahteraan sosial. Sekurang-kurangnya tidak mengorbankan yang satu bagi yang lain (Poole, 1993: 19).

Subjektivitas warga negara Yunani berdasarkan tata bangun konsep-konsep. Sebuah pemahaman tentang konsep-konsep itu lebih meliputi referensi pada konsep-konsep itu dibandingkan semata-mata kekuatan determinasi. Jadi masyarakat Yunani eksis sebagai masyarakat "rohani" dan bukan bentuk masyarakat "alami". Sebagai masyarakat "rohani" hanya dapat eksis sebagai kebajikan dari kekuasaan manusia menginternalisasi dan menggunakan konsep-konsep secara bersama-sama (Walton, 1983: 86).

Meskipun kekurangan subiektivitas reflektif, masyarakat Yunani tergantung pada mahlukmahluk manusia. Mereka menggunakan konsepkonsep dan pandangan hidup yang berasal dari manusia. Manusia Yunani bukan semata-mata sebuah efek dari determinasi psikologis atau struktural. Tetapi sebagai pengada dependen atas kekuasaan konseptual. Masyarakat Yunani menyangkal realisasi diri mereka sepenuhnya. Penyangkalan mereka lakukan melalui penyangkalan terhadap suara hati, pilihan dan kritik individual. Dan juga melalui tuntutan untuk menerima secara tidak reflektif terhadap adatistiadat dan aturan-aturan sosial yang mereka terima. Ini merupakan kontradiksi amat sangat besar yang inheren dalam bentuk sosial itu.

Berdasarkan latar belakang masyarakat Yunani, konsep kekuasaan manusia, menurut Hegel, hanya dapat direalisasikan sepenuhnya dalam sebuah konteks sosial di mana kritisisme individu akan tatanan sosialnya dilegitimasikan, dan di mana susunan institusional merupakan hasil pandangan dan aktivitas individu-individu.

\subsubsection{Civil Society}

Masyarakat Yunani runtuh dengan munculnya subjektivitas, yaitu: warga negara menjadi reflektif dan tidak menerima begitu saja adat istiadat komunitas sebagai kebutuhan yang memadai dalam kebijaksanaan nilainilainya. Kemudian Hegel mendeskripsikan civil society sebagai lahap lebih lanjut dari keluarga.

Hegel mendeifinisikan civil society sebagai:

an association of members as self-subsistent individuals in a universality which, because of their selfsubsistent, is only abstract. Their association is brought about by their needs, by the legal system -the means to security of person and property- and by an external organization for attaining their particular and common interest. 'rhis external state. (Hegel, 1967: 110).

(sebuah perkumpulan anggota sebagai individu-individu yang subsistensi-diri dalam sebuah universalitas yang sama, karena subsistensi-diri mereka, hanya abstrak. Perkumpulan mereka dihasilkan oleh kebutuhankebutuhan mereka, melalui sistem legal cara-cara melindungi person dan barang milik dan dengan sebuah organisasi eksternal bagi pencapaian kekhususan dan kepentingan bersama. Inilah negara eksternal).

Civil society menegaskan sebuah sistem ekonomi tempat anggota-anggota dapat bekerja dan berdagang memuaskan kebutuhan mereka, ditambah institusi-institusi sipil seperti: pasar, pengadilan dan administrasi keadilan publik, kesejahteraan minimal dan sistem antimonopoli.

Individu dalam civil society memiliki kebebasan dan kekayaan yang tercukupi. Kebutuhankebutuhan individu tidak identik dengan pengejaran kebahagiannya, tidak pula sekedar 
memenuhi pemuasan kebutuhan, tetapi usaha memenuhi kesatuan antara pikiran dan tatanan kebutuhan. Maka, dalam membuat pilihan dan ukuran individu tidak dapat kembali pada jaminan tradisional melalui peran-peran, tetapi ia harus memilih ukuran sendiri. Hal ini memperlihatkan bahwa individu merupakan seorang pemilih yang formal dan kosong. Hegel memahami civil society sebagai sebuah medan perang kepentingan-kepentingan pribadi (a battle-field of private interest): Sebagai medan pertempuran, setiap orang dalam civil society saling berhubungan dalam pertentangan. Kepentingan pribadi bertentangan dengan kepentingan bersama, kemudian kedua kepentingan tersebut bersamasama menentang organisasi negara dan konsepkonsep yang lebih tinggi.

Individu-individu yang bebas saling tergantung satu sama lain berdasarkan kepentingan memenuhi kebutuhan masing-masing. Menurut Kolb (1986: 28), civil society dari Hegel adalah ciptaan motif-motif dipusatkan pada diri (selfcentered motives), bukan kebijaksanaan politik dan tindakan kebajikan sebagaimana dituntut masyarakat Yunani. Anggota civil society merasakan tanpa tekanan mengurus segala sesuatu terkecuali syarat-syarat formal dari prosedur keadilan dan syarat-syarat eksternal dari perdagangan dan perjanjian. Ciri khas civil society adalah komunitas itu memberikan strukturstruktur kosong dan formal.

Hegel tidak mengakui individualisme selalu sebagai kebenaran yang tersembunyi dalam dasar-dasar setiap kebudayaan dan masyarakat. Individualisme modern adalah prestasi dari sebuah proses panjang dan merupakan suatu yang baru dalam sejarah kebudayaan Barat. Civil society bukan pengakuan terakhir dari kondisi permanen, hal itu adalah ukuran kondisi baru. Karena struktur intersubjektivitas dan akibat dari individualisme, mengubah tahap yang berbeda dalam sejarah.

Menurut Kolb (1986: 30), sepanjang sejarah Barat, gagasan tentang identitas manusia secara berangsur-angsur dimurnikan dari kesadaran milik bersama. Sebagai contoh: revolusi Perancis. Rakyat mengusahakan masyarakat dan politik yang memiliki struktur pengakuan yang bertitik tolak dari individu-individu sebagai pemilih murni. Tetapi usaha pendefinisian diri ini hanya negatif, karena tidak menempatkan pembatasan kesadaran individu melalui kesadaran bersama.
Hasilnya adalah kehancuran masyarakat.

Definisi individu sebagai mahluk bebas, yang menguasai barang miliknya secara mandiri, mengandung arti kerangka kerja dari interaksi dan peran-peran institusional yang formal. Individu menjadi ahli bukan karena kualitas, dirinya. Individu-individu, dalam civil society, mengakui satu sama lain berdasarkan objek-objek yang mereka miliki. Person modern mengakui sesamanya sebagai seorang individu yang dapat membuat pilihan dan memiliki kebutuhan. Kebutuhan dan pilihan pada suatu dunia didasarkan atas barang milik. Masyarakat mengembangkan kebutuhan-kebutuhan agar struktur sosial sebagai intersubjektivitas dimungkinkan.

Banyak orang mengatakan bentuk kebebasan dari civil society adalah ideal. Tetapi Hegel tidak menyetujui hal tersebut. Hegel mengatakan bahwa bentuk aktualitas individu dalam civil society mengarah pada salah satu dari berbagai macam tatanan yang mungkin untuk organisasi individu-individu yang serupa. Hal ini justru menjadi tempat penghancuran pewatakan parlikularitas dan organisasi, sebaliknya justru kesadaran diri sebagai hasil kebebasan negatif itu yang maju.

Dalam hubungannya dengan keluarga dan negara civil society adalah bentuk komunitas yang menghalangi keluarga sebagai pendasaran negara. Civil society adalah prestasi dari dunia modern yang memberikan determinasi Ide tentang hak. Civil society merupakan kesatuan yang hanya berupa perkongsian. Dalam civil society setiap anggota memillki tujuannya sendiri, orang lain bukan apa-apa bagi dirinya. Orang lain juga memiliki tujuan-tujuan mereka sendiri. Mereka berhubungan dengan sesamanya untuk memenuhi kepentingan mereka sendiri.

Menurut Walton (1983: 68), tujuan perseorangan mengasumsikan sebuah bentuk universalitas melalui hubungannya dengan individu yang lain. Hal ini hanya mungkin dicapai dalam kesejahteraan bersama. Sejak yang partikular tak dapat dielakkan dan tidak mungkin dikondisikan oleh yang universal, wilayah kebersamaan dalam civil society adalah wilayah perantaraan. Di sana berbagai macam permainan bebas dengan segala keanehannya, bakatbakatnya dan setiap bentuk spontanitasnya, lahir dan berkembang. Yang partikular ditentukan yang universal dengan jalan setiap anggota mampu mengembangkan kesejahteraannya sendiri. 


\subsubsection{Negara}

Civil society adalah bentuk negara, dimana perbedaan-perbedaan dan konflik-konflik partikular sangat eksplisit. Kepentingan warga negara dengan negara terbatas pada persoalan hukum perdata dan ekonomi, jadi bukan urusan politik. Individu memisahkan dirinya dari urusan masyarakat. Urusan pribadinya tidak terkait dengan urusan politik dan kesulitan politik tidak menarik perhatiannya.

Menurut Hegel, bersamaan dengan saat terjadinya konflik kepentingan, roh korporasi (corporation spirit) ditimbulkan ketika individu partikular mencapai gelar mereka tentang hak. Sekarang batin diubah menjadi roh negara yaitu sejak negara menegakkan tujuan-tujuan partikularitas warga negara. Inilah rahasia patriotisme warga negara, yaitu: negara menegakkan kepentingan-kepentingan khusus mereka bersama gelar, otoritas, dan mengusahakan kesejahteraan bagi warga negara. Ualam Roh korporasi, sumber partikular dan universal langsung dihadirkan. Oleh karena itu, di dalam Roh yang terdalam dan terkuat, memuat rasa kebangsaan massa rakyat akan negaranya.

Civil society bukan bentuk negara yang hanya berdasarkan teori politik menurut akal budi (Understanding), tetapi juga momen bagi negara yang dimaksud oleh Hegel. Sekarang karena pengaruh pendidikan kehidupan sipil teristimewa kehidupan perdagangan dan perniagaan, membuat individu-individu modern memiliki sisi universal. Hal ini disebabkan mereka bersekutu demi kepentingan ekonomi tanpa harus mengorbankan kebebasan. Persekutuan ini mungkin menjaga kebebasan manusia agar tidak jatuh menjadi individualisme atau manusia yang egois apabila pengawas-pengawas eksternal ditempatkan dalam bentuk kebebasan ini. Disinilah organisasi-organisasi eksternal dibutuhkan manusia. Tetapi jika mereka merealisasikan kebebasan melalui internalisasi prinsip-prinsip dan hal itu menjadi milik mereka, maka sebuah sintesa antara yang universal dan yang partikular menjadi mungkin. Bentuk kebebasan semacam ini hanya mungkin apabila institusi politik negara dibedakan dari civil society. Sebab dalam civil society hukum hanya terbatas pada usaha menjaga keamanan barang milik, dan kontrak dipandang sebagai satu-satunya kekuatan eksternal. Negara didefinisikan oleh Hegel, dengan mengatakan :
The state is the actuality of concrete freedom. But concrete freedom consist in this, that personal individuality and its particular interest not only achieve their complete development and gain explicit recognition for their right... but, for one thing, they also pass over of their own accord into interest of the universal, and, for another thing, they know and will the universal... they take it as their and and aim and are active in its pursuit. The result is that the universal does not prevail or achieve completion except along with particular interest and through the co-operation of particular knowing and willing: and individuals likewise do not live as private persons for their own ends alone, but in the very act of willing these they will the universal in the light of the universal... (Hegel, 1961: 160-161).

(Negara adalah perwujudan dari kebebasan yang kongkrit. Tetapi kebebasan kongkrit yang termuat dalam komunitas ini, individualitas personal dan kepentingan partikularnya tidak hanya mencapai perkembangan mereka selengkapnya dan mencapai pengakuan eksplisit bagi hak-hak mereka... tetapi, untuk suatu hal, mereka Juga mengabaikan persetujuan milik mereka menjadi kepentingan universal, dan bagi hal yang lain, mereka mengetahui, dan menghendaki yang universal... mereka mengambil yang universal sebagai tujuan dan berusaha serta aktif dalam pengejarannya. Hasilnya adalah universal itu tidak berlaku atau mencapai penyelesaian kecuali sepanjang dengan kepentingan-kepentingan partikular dan melalui kerja sama dan kehendak partikular: individu-individu tidak hidup sebagai person-person privat bagi tujuan mereka sendiri, tetapi tindakan dalam menghendaki tujuan ini, mereka menghendaki universal dalam cahaya universal).

Bentuk hubungan-hubungan yang sangat dekat dengan pertanyaan tentang subjektivitas modern adalah bahwa individu-individu masuk ke dalam negara melalui partikularitas objektif. Mereka masuk melalui nilai-nilai dan pandangan hidup, yang mereka pakai bersama-samadalam kelompok.

The member of the state is a member of such a 
group, and it is only as characterized in this objective way that he comes under consideration when we are dealing with the state (Hegel, 1967: 200).

(Anggota negara adalah anggota sebuah group, dan hal itu hanya dicirikan dengan cara objektif bahwa dia sampai di bawah konsiderasi ketika kita memperlakukan negara).

Perubahan perkembangan dalam pemikiran Hegel ini merefleksikan perluasan gerakannya keluar dari aspirasinya tentang ideal komunitas Yunani. Hal itu merupakan gerakan ke arah penggabungan ideal komunitas yang direalisasikan dalam civil society telah mapan sebagai momen yang berbeda. Civil society muncul melalui cara-cara artikulasi dari hak-hak privat, pengakuan validitas hubungan kontraktual, serta hubungan ekonomi bebas yang relatif di antara produsen-produsen dan buruh-buruh.

Kutipan-kutipan tentang negara dari Hegel ini meyakinkan bahwa dalam pandangan Hegel, konteks sosial lebih dipandang sebagai medium dibandingkan subyek atau roh yang subsisten. Hegel memperhitungkan Tatanan sosial Moral modern dengan desakannya atas pengakuan saling ketergantungan antara yang universal dan partikular. Pencantuman civil society sebagai salah satu dari momem-momennya memperlihatkan bahwa gagasan-gasan dalam konteks sosial lebih merupakan medium dibandingkan dengan subjek. Oleh karena itu, Tatanan-Sosial Moral modern dikatakan bertentangan dengan 'Tatanan-Sosial Moral Yunani, karena secara eksplisit Tatanan-Sosial Moral modern dimapankan sebagai medium yang dipergunakan individu dan disusun oleh kembali mereka yang menggunakannya.

Perubahan subjek ke medium dari masyarakat Yunani klasik ke masyarakat modern adalah prestasi dunia modern. Hal itu dicapai melalui artikulasi dan ekspresi beragam kekuatan sosial dan kulturai menciptakan Fenomena individualisme modern. Dan dengan perubahan substansialitas ini, konsep intersubjektivitas ikut berubah.

Perubahan ini sesuai dengan sebuah keunggulan dan legitimasi pada tujuan-tujuan dan proyek-proyek individu. Individu-individu tidak membutuhkan mengambil dari tujuan-tujuan keseluruhan sosial sebaqai milik mereka, tetapi lebih menggambarkan atas konsep-konsep yang ditanamkan dalam keseluruhan sebagai sebuah medium dari rasionalitas dalam mengejar tujuan dan proyek-proyek personal mereka. Dan ini tidak menyangkal bahwa formasi dari tujuantujuan hanya mungkin bersama dengan sebuah konteks sosial. Dalam negara yang dikonsepkan Hegel, menurut Walton (1986:70), tidak dapat menjadi tujuan-tujuan dan proyek-proyek personal yang dipahami secara independen dan lepas dari latar belakang konsep-konsep dan aturan-aturan bersama. Menurut Hegel, di dalam negara dibutuhkan dimensi sosial yang mampu mendeterminasi tujuan-tujuan personal. Tetapi individu-individu tetap dapat memiliki tujuantujuan personal yang eksklusif. Aturan-aturan umum diperuntukkan bagi maksud-maksud "lebih tinggi", artinya, maksud-maksud komunitas sebagai sebuah keseluruhan.

\section{III.PENUTUP}

\subsection{Kesimpulan}

Penelitian konsep intersubjektivitas dalam Phenomenology of Spirit karya G.W.F Hegel menghasilkan kesimpulan sebagai berikut:

1. Subjektivitas merupakan kesadaran-diri yang terkait dengan objek. Subjek dan objek berhubungan secara dialektis. Kebenaran objek tidak semata-mata berasal dari objek itu sendiri tetapi juga ada pengaruh dari subjek. Bahkan dalam konsep tentang Daya (Force), Hegel memahami kebenaran objek terkait dengan hukum universal yang mengada secara objektif dalam realitas.

2. Subjeklivitas individu ditentukan oleh pengakuan subjek lain. Subjektivitas adalah kesadaran kita (we-consciousness): "Aku" adalah "Kita" dan "Kita" adalah "Aku". Subjektivitas bersifat sosial. Kesadaran-diri yang menyadari kehadiran subjek lain tidak memandang subjek itu sebagai objek, tetapi sebagai kesadaran-diri yang identik dengan kesadaran-diri miliknya.

3. Intersubjektivitas bukan hubungan yang telah mapan secara alami, tetapi hasil perjuangan hidup dan mati dari individu-individu yang berjuang memperoleh pengakuan.

4. Hegel memperbaharui konsep intersubjektivitas, yaitu: menempatkan kerja sebagai medium intersubjektivitas.

5. Intersubjektivitas dalam model dialektika 
Tuan dan Budak adalah utopis. Intersubjektivitas yang sungguh-sungguh berdasar pada kesadaran-diri yang mengandung muatan substansi etis objektif.

6. Hegel lebih mengutamakan ini intersubjektivitas dalam wilayah moralitas dibandingkan intersubjektivitas yang bermediasi kerja. Intersubjektivitas di wilayah ekonomi tetap masih terbatas pada hubungan saling menguasai.

7. Roh adalah nilai-nilai dan pengetahuan, mengada secara objektii dalam realitas sosial. Roh mewujud dalam adat-istiadat dan hukum pada masyarakat. Bahasa merupakan wahana perwujudan kesadaran-diri dalam proses internalisasi dan eksternalisasi kandungan Roh.

8. Subjektivitas menginternalisasi dan mengaktualkan isi kandungan Roh melalui proses in- tersubjektif.

9. Hubungan Roh dengan kesadaran ini setiap jaman berubah-ubah, oleh karena itu bentuk intersubjektivitas tiap jaman pun berubahubah.

10.Konsep intersubjektivitas masyarakat modern adalah model hubungan personal yang menghilangkan Roh dari interaksi. Meskipun Roh masih diyakini, tetapi tidak aktual dalam kesadaran subjek. Kesadaran manusia modern di dominasi oleh bidang ekonomi. Bentuk intersubjektivitas di dalam masyarakat modern merupakan wujud krisis kebudayaan. Filsafat tandingan Hegel: intersubjektivitas berdasar pada kekuatan subyek menyatukan diri dengan sesama yaitu berupa pemberian maaf untuk rekonsiliasi dan kesadaran-diri yang memuat substansi Roh. •

\section{DAFTAR PUSTAKA}

Ankersmith, F.R., 1987, Refleksi Tentang Sejarah, Gramedia, Jakarta, terj. Dick Hartoko.

Avineri, S., 1972. Hegel's Theory of the Modern State, UniversiCy Press, Cambridge.

Bakker, A., 1984, Metode-Metode Filsafat, Ghalia Indonesia, Jakarta.

1992, Ontoloyi, Metafisika Umum: Filsafat Pengada dan Dasar-Dasar Kenyataan, Kanisius,

Yogyakarta.

dan A. Charis Zubair, 1991, Metodoloyi Penelilian Filsatat, Kanisius, Yogyakarta.

Berger, P.L., 1992, Pikiran Kembara: Modernisasi dan Kesadaran Manusia, Kanisius, Yogyakarta, terj.

Alouis A. Nugroho.

1990, Revolusi Kapitalis, LP3ES, Jakarta, terj. Hassan Basari .

Bertens, K., 1989, Sejarah Filsafat Yunani, Kanisius, Yogyakarta.

Copleston, F., 1963, A History of Philosophy, vol. VII, Search Press, London. 1962, A History of Philosophy, Vol. I: part 1, Image Books, New York. 1960 a, A History of Philosophy, Vol. VI: part 1, Image Books, New York. 1960 b, A History of Philosophy, Vol. VI: part 2, Image Books, New York. 1963, A History of Philosophy, Vol. VII, Search Press, London. 1968, A History of Philosophy, Vol. V, Burns and Oates Limited, London.

Findlay, J.N. 1977, Fbreword: dalam G.W.F. Hegel: "Phenomenology of Spirit", Claredon Press, Oxford.

Franklin, M., 1960, On Hegel's Theory of Alienation and Its Historic Force, dalam "Tulane Studies in Philosophy: Studies in Hegel": Vol IX, Martinus Nijhoff-The Hague, Netherlands.

Gadacz, T., 1987, Freedom as Reconciliation: the Essence of the Individual's Freedom in the Philosophy of' Hegel, dalam "International Philosophical Quarterly", Vol XXVII: no: 2.

Habermas, J., 1990, Ilmu dan Teknologi Sebagai Ideologi, LP3ES, Jakarta. 1987, The Philosophical Discourse of Modernity, The MIT Press Cambridge, Massachusets. 1974, Theory and Practice, Beacon Press, Boston.

Hamersma, H., 1986, Tokoh-Tokoh Filsafat Barat Modern, Gramedia, Jakarta.

Hardiman, F.B., 1993, Kesadaran yang Tak Bersarang: Refleksi atas Interaksi Kesadaran dan Struktur 
dalam Modernisasi, dalam Tim Redaksi Driyarkara (ed), "Diskursus Kemasyarakatan dan Kemanusiaan", Gramedia Pustaka Utama, Jakarta.

Hegel, G.W.F., 1977, Phenomenology of Spirit, Cloredon Press, oxford.

1975, Science of Logic: the First Part of the Encyclopaedia of the Philosophical Sciences in

Outline, Cloredon Press, oxford.

1967, Philosophy of Right, Cloredon Press, Oxford.

1956, Philosophy of History, Dover Publications Inc., New York.

1968, Hegel's Lectures on The History of Philosophy, Vol. I, Humanities Press, New York.

1968, Hegel's Lectures on The History of Philosophy, Vol. II, Humanities Press, New York.

1968, Hegel's Lectures on The History of Philosophy, Vol. III, Humanities Press, New York.

Hoy, D.C., 1989, Hegel's Critique of Kantian Morality, dalam "History of Philosophy Quarterly", Vol VI

no: 2, New York.

Inwood, M.J., 1983, Hegel, Routlegde \& Kegan Paul, London.

Kant, I., 1959, Critique of Pure Reason, J.M. Dent \& Sons LTD, London.

Kattsoff, L.O., 1987, Pengantar Filsafat, Tiara Wacana, Yogyakarta, terj. Soejono Soemargono.

Kolb, D., 1986, The Critique of Pure Modernity: Hegel, Heidegger and After, the University of Chicago Press, Chicago.

Laeyendecker, L., 1991, Tata, Perubahan dan Ketimpangan: Suatu Pengantar Sejarah Sosiologi, Gramedia Pustaka Ulama, Jakarta, terj. S.S. Samekto.

Magnis-Suseno, F., 1992 a, Berfilsafat dari Konteks, Gramedia Pustaka,Utama, Jakarta. 1992 b, Filsafat Sebagai Ilmu Kritis, Gramedia Pustaka Utama, Jakarta.

1993, Hegel: Filsafat Kritis dan Dialektika, dalam Tim Redaksi Driyarkara (ed), “Diskursus

Kemasyarakatan dan Kemanusiaan", Gramedia Pustaka Utama, Jakarta.

1988, Etika Politik, Gramedia, Jakarta.

Mannheim, K., 1991, Ideologi dan Utopia: Nenyingkap Keterkaitan Pikiran dan Politik, Kanisius, Jakarta, terj. F. Budi Hardiman

Marcuse, H., 1969, Reason and Revolution: Hegel and the Rise of Social Theory, Routledge \& Kegan Paul LTD, London.

Marx, W., 1975, Hegel's Phenomenology of Spirit: Its Point and Purpose A Commentary on the Preface and Introduction, Harper \& Row Publishers, New York.

Poole, R. 1993, Moralitas dan Modernitas: Di Bawah Bayang-bayang Nihilisme, Kanisius, Yogyakarta, terj. F. Budi Hardiman.

Rosen, S., 1979., G.W.F. Hegel: Introduction to Science of Wisdom, Yale University Press, London.

Santre, J.P., 1959., Being and Nothingness: an Essay on Phenomenological Ontology, Philosophical Library Inc., New York.

Schroorl, J.W., 1980, Modernisasi: Pengantar Sosiologi Pembangunan Negara-negara Sedang Berkembang, Gramedia, Jakarta, R.G. Soekadijo.

Scruton, R., 1986, Sejarah Singkat Filsafat Modern: dari Desacartes sampai Wittgenstein, Pantja Simpati, Jakarta.

Shindunata, 1983, Dilema Usaha Manusia Rasional: Kritik Masyarakat Modern oleh Marx Horkheimer dalam Rangka Sekolah Frankfurt, Gramedia, Jakarta.

Silitonga, S., 1977, Mitologi Yunani, Djambatan, Jakarta

Slace, W.T., 1955, The Philosophy of Hegel, Dover Publication, USA.

Tjahyadi, S.P.L., 1990, Hukum Moral: Ajaran Immanuel Kant Tentang Etika dan Imperatif Kategoris, Kanisius, Yogyakarta.

Walsh, W.H., 1969, Hegelian Ethics, St Martin's Press, New York.

Walton, A.S., 1983, Hegel: Individual Agency and Social Context, dalam Lawrence S. Stepelevich \& David Lamb (ed), "Hegel's Philosophy of Action", Humanities Press, New York.

Weslphal, M., 1979, History and Truth in Hegel's Phenomenology, Humanities Press Inc., New York.

Windelband, W., 1959, A History of Philosophy, Vol. II, Harper Torchbooks, New York.

Woolf, H.H. (ed), 1975, Webster's New Collegiate Dictionary, G. \& C. Merriam Company, Massachussetts. 